\title{
A dynamic explanation for the origin of the western Mediterranean organic-rich layers
}

M. Rogerson

Department of Geography, University of Hull, Cottingham Road, Hull HU17 OJF, UK (m.rogerson@hull.ac.uk)

\section{Cacho}

GRC Geociències Marines, Departamento de Estratigrafia i Paleontologia i Geociències Marines, Facultat de Geologia, Universitat de Barcelona, C/ Martí Franques s/n, E-08028 Barcelona, Spain

\section{F. Jimenez-Espejo}

Instituto Andaluz de Ciencias de la Tierra (CSIC-UGR), Facultad de Ciencias, Avenida Fuentenueva s/n, E-18002 Granada, Spain

Institute for Research on Earth Evolution, Japan Agency for Marine-Earth Science and Technology, Natsushima-cho 2-15, Yokosuka 237-0061, Japan

\section{I. Reguera and F. J. Sierro}

Departamento de Geología, Facultad de Ciencias, Universidad de Salamanca, Plaza La Merced s/n, E-37008, Salamanca, Spain

\section{F. Martinez-Ruiz}

Instituto Andaluz de Ciencias de la Tierra (CSIC-UGR), Facultad de Ciencias, Avenida Fuentenueva s/n, E-18002 Granada, Spain

\section{J. Frigola and M. Canals}

GRC Geociències Marines, Departamento de Estratigrafia i Paleontologia i Geociències Marines, Facultat de Geologia, Universitat de Barcelona, C/ Martí Franques s/n, E-08028 Barcelona, Spain

[1] The eastern Mediterranean sapropels are among the most intensively investigated phenomena in the paleoceanographic record, but relatively little has been written regarding the origin of the equivalent of the sapropels in the western Mediterranean, the organic-rich layers (ORLs). ORLs are recognized as sediment layers containing enhanced total organic carbon that extend throughout the deep basins of the western Mediterranean and are associated with enhanced total barium concentration and a reduced diversity (dysoxic but not anoxic) benthic foraminiferal assemblage. Consequently, it has been suggested that ORLs represent periods of enhanced productivity coupled with reduced deep ventilation, presumably related to increased continental runoff, in close analogy to the sapropels. We demonstrate that despite their superficial similarity, the timing of the deposition of the most recent ORL in the Alboran Sea is different than that of the approximately coincident sapropel, indicating that there are important differences between their modes of formation. We go on to demonstrate, through physical arguments, that a likely explanation for the origin of the Alboran ORLs lies in the response of the western Mediterranean basin to a strong reduction in surface water density and a shoaling of the interface between intermediate and deep water during the deglacial period. Furthermore, we provide 
evidence that deep convection had already slowed by the time of Heinrich Event 1 and explore this event as a potential agent for preconditioning deep convection collapse. Important differences between Heinrich-like and deglacial-like influences are highlighted, giving new insights into the response of the western Mediterranean system to external forcing.

Components: 11,571 words, 7 figures, 2 tables.

Keywords: sapropel; Mediterranean; sea level; paleoceanography; circulation.

Index Terms: 4962 Paleoceanography: Thermohaline; 1641 Global Change: Sea level change (1222, 1225, 4556).

Received 24 December 2007; Revised 18 April 2008; Accepted 9 May 2008; Published 8 July 2008.

Rogerson, M., I. Cacho, F. Jimenez-Espejo, M. I. Reguera, F. J. Sierro, F. Martinez-Ruiz, J. Frigola, and M. Canals (2008), A dynamic explanation for the origin of the western Mediterranean organic-rich layers, Geochem. Geophys. Geosyst., 9, Q07U01, doi:10.1029/2007GC001936.

Theme: Circum-Iberia Paleoceanography and Paleoclimate: What Do We Know?

Guest Editors: F. Abrantes, M. Fernanda Sanchez-Goni, C. Ruehlemann, and A. Voelker

\section{Introduction}

[2] The eastern Mediterranean sapropels are among the most intensively investigated phenomena in the paleoceanographic record [Cramp and O'Sullivan, 1999]. Consequently, the mechanisms underlying their origin have been discussed in detail, providing a solid understanding of the behavior and sensitivity of the Eastern Mediterranean system [Bethoux and Gentili, 1999; Casford et al., 2003; Cramp and O'Sullivan, 1999; Kallel et al., 1997; Rohling, 1994; Rohling et al., 2002]. In contrast, though they have been known since the early 1980s [Canals et al., 1982], very few studies have analyzed the occurrence and origin of sapropel formation in the western Mediterranean, the so-called organic-rich layers (ORLs), and despite their similarity to the sapropels their mode of origin is not so well understood [Cacho et al., 2002b]. Increasing our understanding of these western ORLs will give new insights into our understanding of the Mediterranean system as a whole and its sensitivity to external forcing.

[3] Western Mediterranean ORLs are recognized as sediment layers containing enhanced total organic carbon (TOC) (up to $0.9 \%$ mass [Cacho et al., 2002b; Martinez-Ruiz et al., 2003]) that extend throughout the deep basins of the Western Mediterranean, including both the deep Tyrrhenian and the Alboran Sea sub-basins [Meyers and Arnaboldi, 2005]. ORL deposits are associated with enhanced total barium concentration $\left(\mathrm{Ba}_{\text {tot }}\right)$ [Jimenez-Espejo et al., 2007a; Krishnamurthy et al., 2000; Meyers and Arnaboldi, 2005] and a reduced diversity benthic foraminiferal assemblage, with a species composition indicative of dysoxic, but not anoxic, conditions (Globobulimina and Chilostomella species are dominant, and Cibicidoides and Gyroidina species are present but sparse [Cacho et al., 2002b]). Only in the Tyrrhenian Sea are ORLs expressed as truly anoxic, sapropel-like layers [Krishnamurthy et al., 2000]. Consequently, ORLs are thought to represent periods of enhanced productivity, presumably related to increased continental runoff [Meyers and Arnaboldi, 2005], and this process is clearly important in providing sufficient organic matter to overcome the supply of oxygen. However, as pointed out by Bethoux and Gentili [1999], for bottom anoxia to be caused by changes in productivity alone, the flux of carbon out of the surface layer would have to increase by a factor of 4. As in the case of the eastern sapropels, it is more likely that enhanced productivity was coupled with a reduced bottom circulation that restricted the amount of oxygen available for carbon respiration [Casford et al., 2003]. In all these respects, ORLs are comparable to weakly expressed ("ghost") sapropels [Jung et al., 1997; Larrasoaña et al., 2006], prompting researchers to search for a similar atmospherically forced mechanism for their origin.

\subsection{So Why Are ORLs Not Simply "Ghost" Sapropels?}

[4] The most important difference between ORLs and sapropels is that they were deposited during different time intervals. Whereas the eastern sap- 
ropels were deposited immediately subsequent to precession maxima and the best known examples (e.g., S1, S5 [Rohling, 1994]) occur over periods of $3-5.5 \mathrm{ka}$ at the beginning of interglacial periods, the last two ORLs occur at glacial Terminations (I and II) and extend over periods $\sim 5-6 \mathrm{ka}$ positioned directly at the orbital maximum. Consequently, ORLs do not share the apparently constant lag of the eastern sapropels relative to precession [Rohling and Hilgen, 1991]. The timing of deposition of ORLs therefore does not tally with the well known pluvial maxima in North Africa [Larrasoaña et al., 2003], and so an enhanced runoff mechanism linked to displacements of the ITCZ for the formation of the ORLs, comparable to that of the sapropels, is difficult to sustain. To highlight these temporal differences between sapropels and ORLs, we here investigate the case of ORL 1 in detail. Within the Alboran Sea, onset of ORL 1 occurred at $14.5 \mathrm{ka}$ (4.5 ka prior to onset of sapropel S1) and deposition spanned the BøllingAllerød, the Younger Dryas, and early Holocene. ORL 1 termination is associated with the $\sim 8.2 \mathrm{ka}$ climatic event [Cacho et al., 2002b]. Consequently, deposition of S1a in the Eastern Mediterranean Sea occurred synchronously to the last deposition phase of the ORL 1 [Martinez-Ruiz et al., 2003]. A newly published record of WMDW flow on the Balearic slope [Frigola et al., 2008] shows the persistence of a weak deep water current during Termination 1 and a sudden increase during the $8.2 \mathrm{ka}$ climatic event. This study highlights the potential role of sea level rise slowing down Western Mediterranean deep overturning, an hypothesis which requires further exploration.

\subsection{Precipitation/Evaporative Flux as a Mechanism for Forcing Development of Western ORLs}

[5] Pollen, speleothem and lake-derived precipitation records indicate significant variability in the evaporative flux during the last deglacial period throughout the Mediterranean region [Allen and Huntley, 1996; Allen et al., 2000; Bar-Matthews et al., 2003; Causse et al., 2003; Perez-Obiol and Julia, 1994; Rossignol-Strick, 1999]. Particularly, regional pollen diagrams suggest an alternation between warm/humid and cool/arid conditions in the northwest Mediterranean during the BøllingAllerød and Younger Dryas periods [Allen and Huntley, 2000; Allen et al., 2000; Naughton et al., 2007; Perez-Obiol and Julia, 1994]. Consequently, an excess of precipitation seems unable to be the main forcing for the ORL 1 formation, particularly as it terminated within the period associated with the greatest precipitation in the eastern Mediterranean catchment [Bar-Matthews et al., 2003; Rossignol-Strick, 1999]. The fact that ORL deposition does not share the lag with precession typical of sapropels [Rohling and Hilgen, 1991] also indicates that it is not forced by the same changes in atmospheric circulation.

[6] Nevertheless, even assuming constant net evaporative flux, river runoff could play some role in altering the state of deep water formation, via altering the spatial/seasonal distribution of freshwater discharge. Records of runoff (sedimentary $\mathrm{K} / \mathrm{Al}$ ) in the northwestern Mediterranean, close to the WMDW sinking cell, display a strong relationship with precession, and consequently peak during the period of deposition of ORL1 [Frigola et al., 2008]. This increase in runoff may not necessarily reflect more humid conditions, but could reflect regional changes in the pluviosity regime. The presence of high mountain ranges throughout the western Mediterranean hinterland (e.g., the Alps, Betics and Atlas), especially those on the northern margin, provide the potential for a large amount of freshwater to be stored within the system as glaciers. Cosmogenic dating of Alpine glacier retreat suggests maximum retreat rates between 15.4 and $14 \mathrm{ka}$ and 12.1 and $11 \mathrm{ka}$ [IvyOchs et al., 2007; Kelly et al., 2006]. It is therefore also possible that deglacial shrinkage of this reservoir of stored freshwater may have contributed to decoupling of the local runoff and precipitative fluxes during the deglaciation.

\subsection{Aim of This Study}

[7] Here, we show that the timing of the deposition of the most recent ORL in the Alboran Sea is indeed different than that of the approximately coincident sapropel, indicating that there are important differences between the modes of formation of ORLs and sapropels. We provide geochemical evidence indicating onset of reducing bottom conditions and enhanced burial of organic matter related to ORL1 occurred well before onset of enhanced TOC burial in the eastern Mediterranean. We go on to demonstrate through physical arguments that a likely explanation for the origin of these Alboran ORLs lies in the response of the Western Mediterranean basin to a strong reduction in surface water density during deglacial periods, in conjunction with secondary factors such as changes in atmospheric processes. This argument is similar to that anticipated by Rohling [1994]. 
[8] Given the considerable complexity of the western Mediterranean freshwater system (outlined in section 1.2), we will not directly investigate the impact of changes in evaporative flux in this study. We seek to provide an oceanographic context into which empirically derived freshwater "hosing" concepts can be placed. However, the recent observation that Heinrich Events (HEs) penetrated into the Alboran Sea and even further north into the NW Mediterranean Sea [Sierro et al., 2005] provides a further significant source of freshwater external to precipitation that it is possible to constrain in terms of fluxes. Though this influx of freshened surface water occurred $\sim 1.5 \mathrm{ka}$ earlier than onset of deposition of ORL 1, it is expected to be extremely large and therefore cannot be overlooked even if only as a preconditioning agent. Consequently, we provide estimates of the impact of this freshening to the western Mediterranean internal circulation.

\section{Hydrography of the Western Mediterranean}

[9] The hydrography of the western Mediterranean is comprehensively discussed by Millot [1987, 1999], and only a brief description is necessary here. The western Mediterranean essentially represents a reservoir within the Mediterranean Strait System [Astraldi et al., 1999], in which water taking part in the Mediterranean anti-estuarine circulation is stored before being exchanged at its western and southeastern limits. Consequently, it is characterized by net transport from west to east in its upper layers $(0$ to $\sim 200 \mathrm{~m}$ ) and east to west transport in its lower layers. Five important water types take part in this circulation, which are as follows, in order of increasing density: (1) Modified Atlantic Water (MAW), which is essentially North Atlantic Central Water drawn into the Mediterranean through the Strait of Gibraltar; (2) Winter Intermediate Water (WIW), which forms from MAW as a result of moderate winter cooling and evaporation along the northern margin of the western Mediterranean; (3) Levantine Intermediate Water (LIW), formed in the eastern Mediterranean and entering the western Mediterranean as the lower limb of the exchange through the Strait of Sicily; (4) Tyrrhenian Dense Water (TDW), which is formed from mixing of East Mediterranean Deep Water (which enters the western basin via the Strait of Sicily as a minor layer below LIW) and intermediate waters in the Tyrrhenian Sea and forms a spatially complex layer below LIW; and (5) West
Mediterranean Deep Water (WMDW), which is formed by intense winter cooling and evaporation in the Gulf of Lions and forms the bottom layer within all of the deep basins in the western Mediterranean. Of these, MAW is the major water mass undergoing transport from west to east and LIW is the major water mass undergoing transport from east to west, though some TDW and WMDW is known to be exported to the Atlantic via the Strait of Gibraltar [Millot, 1987, 1999; Millot et al., 2006].

\section{Methods}

\subsection{Material and Chronostratigraphy}

[10] Four cores spanning the last $20 \mathrm{ka}$ positioned at water depths $(\sim 1500$ to $\sim 2500 \mathrm{~m})$ currently occupied by WMDW have been used for this study (Figure 1 and Table 1). Two cores are situated in the Alboran basin (MD95-2043 and TTR14-300G). Results on MD95-2043 have been published previously [Cacho et al., 1999, 2002a, 2006] and consist of alkenone-derived sea surface temperature (SST), total organic carbon (TOC), total C37alkenone content and $\delta^{13} \mathrm{C}$ data from the benthic foraminiferan Cibicidoides pachydermus. The chronostratigraphic models for the studied interval is based on $16{ }^{14} \mathrm{C}$ accelerator mass spectrometry (AMS) dates measured on monospecific planktonic foraminifers and calibrated to calendar years using the Calib 4.1 software [Stuiver and Reimer, 1993] and the INTCAL 98 calibration database [Stuiver et al., 1998] and a 400 year reservoir effect (for further details, see Cacho et al. [1999]). Though both the software and calibration database used here have been superseded, we retain this original chronostratigraphy due to its proven success in accurately placing millennial-scale events in MISs 2 and 3 [Rohling et al., 2003]. Chronostratigraphy for core $300 \mathrm{G}$ is based on $5{ }^{14} \mathrm{C}$ AMS dates measured on monospecific planktonic foraminifers (Table 2), treated in the same way as dates for MD95-2043, albeit with the Calib 5 software and the INTCAL 04 calibration database [Reimer et al., 2004]. Again, a reservoir correction of 400 years was used.

[11] Two further cores are located in the AlgeroBalearic basin (ODP site 975B and MD99-2343). Chronostratigraphies are based on 5 and $10{ }^{14} \mathrm{C}$ AMS dates, treated in the same way as dates for MD95-2043 (Table 2), again using the more recent Calib 5 software and the INTCAL 04 calibration database [Reimer et al., 2004]. Again, a reservoir correction of 400 years was used. Results for 975B have been previously published [Jimenez-Espejo et 


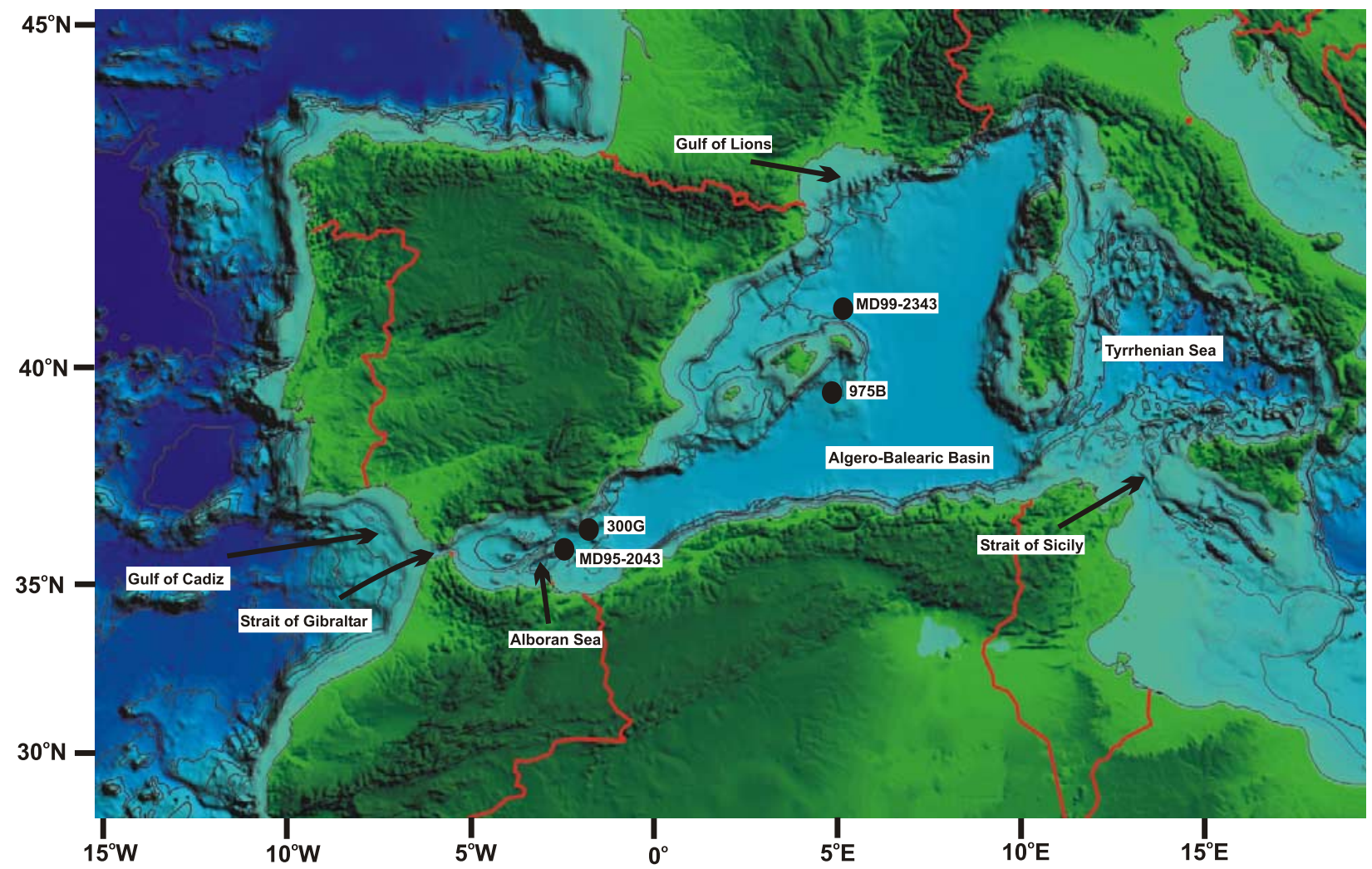

Figure 1. Geography of the western Mediterranean Sea and locations of cores used in this work.

al., 2007a, 2007b]. Core MD99-2343 is located close to the source region of WMDW (Gulf of Lions), and primarily used to indicate changes in the velocity of this water mass as it settles to the bottom [Frigola et al., 2008]. The location of these cores are shown in Figure 1 and Table 1.

\subsection{Geochemical and Sedimentological Measurements}

[12] Molecular biomarkers (C37 alkenones) were analyzed with a Varian gas chromatograph Model 3400 equipped with a septum programmable injector and flame ionization detection and SSTs were estimated from the relative concentration of $\mathrm{C} 37$ alkenones [Cacho et al., 1999]. Total organic carbon (TOC) content was determined with a Carlo-Erba (NA 1500) Elemental Analyzer [Cacho et al., 2002a].
[13] Stable isotope measurements were carried out on the planktic foraminifer $G$. bulloides (25-30 well-preserved specimens picked from the 300$355 \mu \mathrm{m}$ size) and on the benthic foraminifer Cibicidoides pachydermus (5-10 specimens picked from the $250-500 \mu \mathrm{m}$ fraction). These measurements were made with a SIRA mass spectrometer equipped with a VG isocarb common acid bath system. Analytical reproducibility of laboratory standards was better than $0.08 \%$ for $\delta^{18} \mathrm{O}$ and $0.04 \%$ for $\delta^{13} \mathrm{C}$. Calibration to VPDB is via the NBS19 standard [Cacho et al., 1999, 2006].

[14] Grain-size analyses of the terrigenous fraction was measured with a Coulter LS 100 Laser Particle Size Analyzer. Grain size distribution is presented using the UP10 index which represents the percentage of particles coarser than $10 \mu \mathrm{m}$ [Frigola et al., 2008].

Table 1. Core Information

\begin{tabular}{|c|c|c|c|c|}
\hline & \multicolumn{2}{|c|}{ Alboran Basin Core } & \multicolumn{2}{|c|}{ Algero-Balearic Basin Core } \\
\hline & TTR14-300G & MD95-2043 & MD99-2343 & ODP161-975B \\
\hline Latitude & $36^{\circ} 21.532^{\prime} \mathrm{N}$ & $36^{\circ} 8.6^{\prime} \mathrm{N}$ & $40^{\circ} 29.84^{\prime} \mathrm{N}$ & $38^{\circ} 53.795^{\prime} \mathrm{N}$ \\
\hline Longitude & $1^{\circ} 47.507^{\prime} \mathrm{W}$ & $2^{\circ} 37.3^{\prime} \mathrm{W}$ & $4^{\circ} 1.69^{\prime} \mathrm{E}$ & $4^{\circ} 30.596^{\prime} \mathrm{E}$ \\
\hline Depth (m) & 1860 & 1841 & 2391 & 2416 \\
\hline
\end{tabular}


Table 2. The ${ }^{14} \mathrm{C}$ Datings Used and Results of AMS ${ }^{14} \mathrm{C}$ Carbon Dating of Monospecific Samples of G. bulloides $(>125 \mu \mathrm{m})^{\mathrm{a}}$

\begin{tabular}{rcccc}
\hline Lab. Code & Sample Description & Core Depth & Conventional Age & Calibrated Age \\
\hline TTR14-300G & & & & \\
Poz-21172 & $300 \mathrm{G} / 01 / 9-10.5$ & $10 \mathrm{~cm}$ & $1390 \pm 30$ B.P. & $835 \pm 55$ \\
Poz-21173 & $300 \mathrm{G} / 01 / 24-25.5$ & $25 \mathrm{~cm}$ & $2440 \pm 35$ B.P. & $1956 \pm 70$ \\
Poz-14597 & $300 \mathrm{G} / 02 / 17-19.5$ & $75 \mathrm{~cm}$ & $6470 \pm 40$ B.P. & $6910 \pm 80$ \\
Poz-14188 & $300 \mathrm{G} / 03 / 54-56.5$ & $168 \mathrm{~cm}$ & $11690 \pm 60$ B.P. & $13150 \pm 65$ \\
Poz-12157 & $300 \mathrm{G} / 04 / 6-7.5$ & $179 \mathrm{~cm}$ & $11890 \pm 60$ B.P. & $13300 \pm 65$ \\
975B & & & & \\
KIA 27327 & $975 \mathrm{~B} / 1 / 8-10$ & $9 \mathrm{~cm}$ & $2455+30 /-25$ B.P. & $2049 \pm 54$ \\
KIA 27328 & $975 \mathrm{~B} / 1 / 50-52$ & $51 \mathrm{~cm}$ & $7070+40 /-35$ B.P. & $7519 \pm 42$ \\
KIA 27329 & $975 \mathrm{~B} / 1 / 90-92$ & $91 \mathrm{~cm}$ & $13330 \pm 60$ B.P. & $15201 \pm 135$ \\
KIA 27330 & $975 \mathrm{~B} / 1 / 130-132$ & $131 \mathrm{~cm}$ & $15870 \pm 80$ B.P. & $18768 \pm 67$ \\
KIA 27331 & $975 \mathrm{~B} / 2 / 45-47$ & $190 \mathrm{~cm}$ & $19460 \pm 110$ B.P. & $22512 \pm 114$ \\
\hline
\end{tabular}

${ }^{\text {a }}$ Calibration has been made using Calib 5.0 software. A reservoir effect of 400 years has been applied.

[15] Analyses for common elements (Mn, Al) were performed by atomic absorption spectrometry (AAS) (Perkin-Elmer 5100 spectrometer, at the University of Granada, Spain) with an analytical error of $\sim 2 \%$. Analyses of trace elements (Th, U) were performed using inductively coupled plasmamass spectrometry (ICP-MS, Perkin-Elmer Sciex Elan 5000, Analytical Facilities of the University of Granada, Spain) following $\mathrm{HNO}_{3}+\mathrm{HF}$ digestion of $100 \mathrm{mg}$ of powder samples. The instrumental error is $\pm 2 \%$ and $\pm 5 \%$ for elemental concentrations of 50 and $5 \mathrm{ppm}$, respectively. These methods are described in detail by Jimenez-Espejo et al. [2007b].

[16] Here, we use the ratios of $\mathrm{Mn} / \mathrm{Al}$ and $\mathrm{U} / \mathrm{Th}$ as proxies for past redox conditions at the sediment surface, following the approach of Mangini et al. [2001]. Aluminum and thorium are insoluble both under oxidizing and reducing conditions, and so are rather immobile in marine sediment. Manganese is highly soluble under reducing conditions and highly insoluble under oxidizing conditions, and consequently tends to be transported out of regions of reduced oxygen. Periods of reducing bottom conditions therefore tend to cause the deposition of sediment depleted in $\mathrm{Mn}$, and therefore show reduced $\mathrm{Mn} / \mathrm{Al}$. Though this behavior is well established the redox behavior of $\mathrm{Mn}$ is not simple, and the rate of export will also depend on other local biogeochemical conditions [Trouwborst et al., 2006]. Consequently, changes in sedimentary $\mathrm{Mn} / \mathrm{Al}$ may only be employed as a relative indicator of redox conditions, with low (high) values indicating relatively high (low) export and thus low (high) average Eh. The reverse redox behavior is true of uranium, meaning that $\mathrm{U} / \mathrm{Th}$ varies inversely to $\mathrm{Mn} / \mathrm{Al}$. Post-depositional "burn-down" is known to significantly modify sedimentary U/Th signals, so this parameter must be interpreted with caution [Mangini et al., 2001].

\subsection{Estimation of Past Changes in WMDW Density}

[17] Estimation of changes in the density of the new West Mediterranean Deep Water produced at the surface during the last deglaciation are derived from representative values for the changes in mean Mediterranean salinity and the sea surface temperature in the northwestern Mediterranean during the winter (wSST), which are the location and season of WMDW production [Stommel, 1972]. Densities stated are $\sigma_{1}$ values, and the approximation of the equation of state for seawater used is taken from [Levitus and Isayev, 1992]. The wSST record used for the western Mediterranean here is a planktonic foraminiferal assemblage-derived record from the Menorca core MD99-2343 [Reguera, 2004]. Winter temperatures were obtained using the modern analog method (MAT). The database used was that of Kallel et al. [1997] for the Mediterranean Sea, which comprise 253 core top samples (128 from the Mediterranean Sea and 123 from the North Atlantic Ocean).

[18] Two components are used to calculate changes in mean Mediterranean salinity. First, we consider the changes in mean Atlantic salinity caused by melting of the Last Glacial Maximum (LGM) ice sheet [Schrag et al., 2002]. This is calculated following the approach of Matthiesen and Haines [2003] according to the statement

$$
S_{\text {atl }}=S_{\text {atl }}^{\text {present }} \frac{H_{\text {Global ocean }}}{H_{\text {Global ocean }}-h^{\prime}}
$$

where $S_{\text {atl }}^{\text {present }}=36 \mathrm{psu}, \mathrm{H}_{\text {Global ocean }}=3800 \mathrm{~m}$ and $\mathrm{h}^{\prime}$ is relative sea level change derived from the 


\section{Gibraltar $\quad$ Alboran Sea}

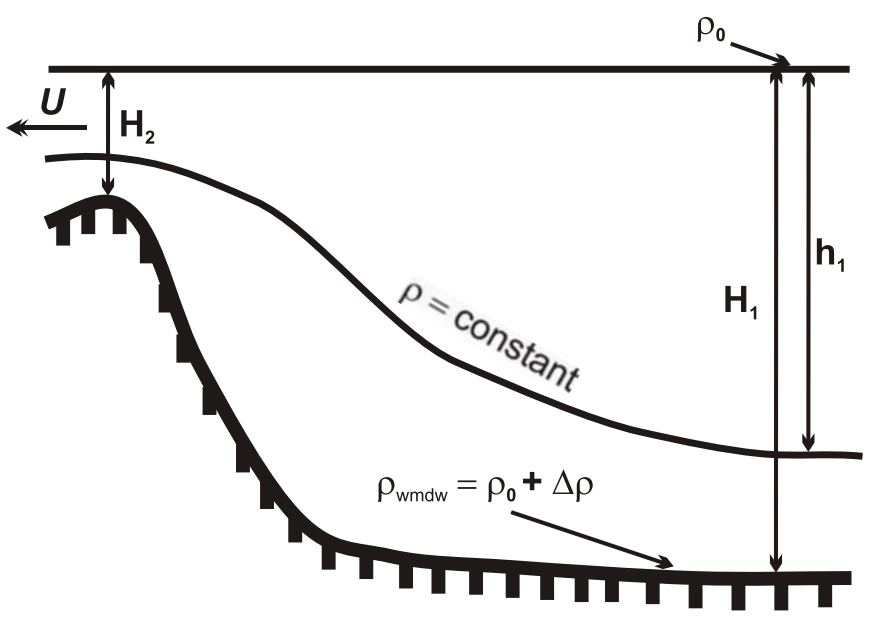

Figure 2. Schematic of the parameters involved in Bernoulli aspiration (equation (2)) (modified from Seim and Gregg [1997]).

coral-based sea level record [Bard et al., 1996; Fairbanks, 1989].

[19] Second, we consider changes in the salinity difference between the Atlantic and Mediterranean water masses across the Strait of Gibraltar $\left(\Delta \mathrm{S}_{\text {gib }}\right)$. Here we use previously published values for $\Delta \mathrm{S}_{\text {gib }}$ for the last deglacial period [Rogerson et al., 2006; Rohling and Bryden, 1994]. This approach employs a hydraulic control model in combination with mass and salt conservation statements [Bryden and Kinder, 1991] under the assumptions of exchange at Gibraltar being maximal and constant net evaporation.

[20] As discussed above, we specifically do not consider the impact of varying evaporative flux in the Mediterranean basin. However, as the impact of HE 1 is considered potentially important, we do incorporate the impact of this influx of freshwater into our model. The record of $\delta^{18} \mathrm{O}_{\text {water }}$ presented by Sierro et al. [2005] for the interval of HE 1 indicates a roughly $1 \%$ excursion to light values centered on approximately $16 \mathrm{ka}$. The ${ }^{16} \mathrm{O}$ responsible for this excursion is thought to be derived from the melting of icebergs, which likely have a $\delta^{18} \mathrm{O}$ composition in the region of -10 to -20 [Rohling and Cooke, 1999]. Consequently, Heinrich Event 1 can be considered to have freshened MAW by $5-10 \%$. Using a baseline value for $S_{\text {atl }}$ taken from equation (1) (37.5 PSU), 5-10\% freshening suggests a change of $\sim 3.8-1.9$ PSU. This range of values can then be used to represent the change in $\Delta \mathrm{S}_{\mathrm{gib}}$ and the salinity of water in MAW and propagated though our model. We assume that any impact on SST is included in the empirical records used and so impose no adjustment in thermal parameters. It is important to note that changing $\Delta \mathrm{S}_{\text {gib }}$ influences net exchange at Gibraltar, which is estimated to have increased by $\sim 0.1-0.2 \mathrm{~Sv}$ as a result of the Atlantic freshening.

\subsection{Estimation of Past Changes in Aspiration of WMDW Over the Camarinal Sill}

[21] The Camarinal sill is the shallowest section within the Strait of Gibraltar (maximum depth $284 \mathrm{~m}$ ), and it is in this section that the two-layer Froude number exceeds 1 [Bryden et al., 1988]. Consequently, it is considered to represent the primary hydraulic control on westward flux of Mediterranean water into the Atlantic [Farmer and Armi, 1986]. As the interface of WMDW and LIW (defined by the $12.90^{\circ} \mathrm{C}$ isotherm today) lies at $\sim 700 \mathrm{~m}$, more than $400 \mathrm{~m}$ lower than the level of the Camarinal Sill, WMDW is only exported through the Strait of Gibraltar due to the process of Bernoulli aspiration or "suction" [Kinder and Parilla, 1987; Stommel et al., 1973]. The force available for this aspiration is derived from the shear imparted by westward movement of the LIW to the WMDW immediately below the interface between these water masses. To illustrate the direction and magnitude of changes in aspiration during the period of ORL1 deposition, we here follow previous authors [Kinder and Bryden, 1990; Seim and Gregg, 1997; Stommel et al., 1973] in representing this aspirational force as the maximum depth from which WMDW can be transported to sill depth. This is equivalent to the depth at which the 

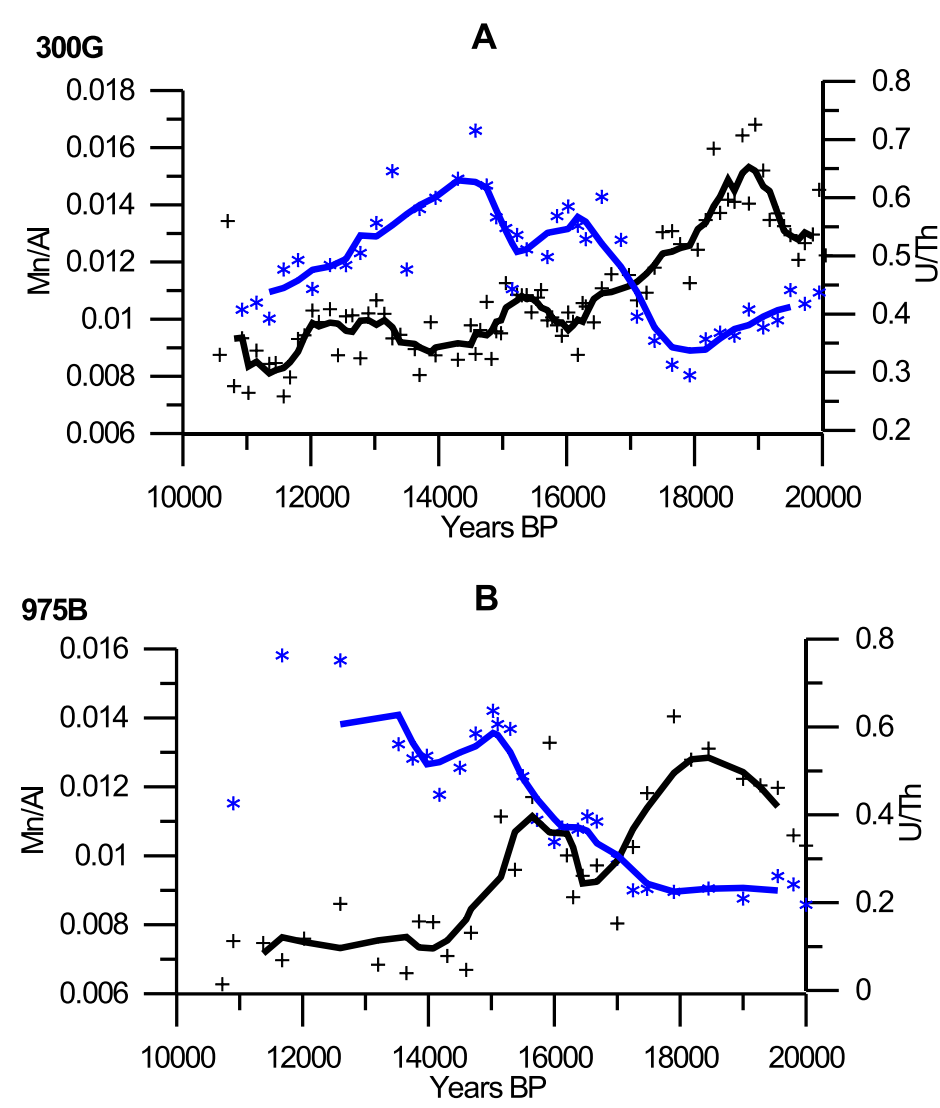

Figure 3. Bulk geochemical data for Alboran Sea and Algero-Balearic cores. Black data represents Mn/Al; blue data represents U/Th. Lines are 3-point moving averages. U and Th were obtained by ICP-MS in both cores; Mn and Al we obtained by AA in core $975 \mathrm{~B}$ and using XRF in core $300 \mathrm{G}$. Onset of sapropel S1 is at $\sim 10 \mathrm{ka}$ B.P.

velocity imparted to the WMDW by motion of the LIW = 0. Seim and Gregg [1997] provide a simple formulation for this "stagnation depth," showing that

$$
h_{1}=0.5 H_{2}+\left(0.25 H_{2}^{2}+\frac{U^{2}}{g \Delta \rho / \rho_{0} H_{1}}\right)^{1 / 2}
$$

where $U$ is the velocity of LIW at the sill, $g$ is the acceleration due to gravity $\left(\sim 9.78 \mathrm{~m} \mathrm{~s}^{-2}\right)$ and the other parameters are as shown in Figure 2. The depth terms $\mathrm{H}_{1}$ and $\mathrm{H}_{2}$ can be derived by subtracting the relative sea level change $\left(h^{\prime}\right)$ from the modern depths of the Alboran Sea ( 2000 m) and the Camarinal Sill (284 m), respectively. The density of the surface layer $\left(\rho_{0}\right)$ is calculated using the Levitus and Isayev [1992] relationship from reconstructed values for salinity and temperature of MAW in the Alboran Sea, as done above for WMDW. Salinity of MAW is estimated assuming that, within the Alboran Sea, inflowing Atlantic water has undergone only minor modification, and so is taken from equation (1). Temperature values are taken from the alkenone SST record from core MD95-2043 [Cacho et al., 1999]. Alkenonederived SST is biased toward the cold season, especially the autumn in the Mediterranean [Ternois et al., 1996]. The SST record used is therefore close to but slightly cooler than annual mean conditions in the surface layer. To investigate how important the seasonal bias might be, we reconstruct aspiration histories for the alkenone SST values and for SST increased by 1,2 and $4^{\circ} \mathrm{C} . \Delta \rho$ is derived from the difference between $\rho_{0}$ and the density of WMDW taken from the calculation in section 3.3. Proportional changes in $U$ are determined from the proportional change in $\Delta S_{\text {gib }}$ taken from section 3.3, assuming that

$$
U_{t}=U_{\text {Holocene }}\left(\Delta S_{\text {gib }}{ }^{\prime} / \Delta S_{\text {gib }}\right)
$$

where $U_{t}$ is the velocity of LIW at time $t, \Delta S_{g i b}$ is the salinity difference at Gibraltar today, $\Delta S_{g i b}{ }^{\prime}$ is the salinity difference at Gibraltar at time $t$ and $U_{\text {Holocene }}$ is the maximum velocity of the outflow of water in the Strait of Gibraltar today. Here, we 
use a value for $U_{\text {Holocene }}$ of $2 \mathrm{~m} \mathrm{~s}^{-1}$ [Tsimplis and Bryden, 2000]. As HE 1 impacted on $\Delta S_{\text {gib }}$ as described in section 2.6, it is necessary to consider the impact of this freshening on aspiration depth in addition to changes relating to the deglaciation. We will discuss the role of LIW dynamics during the Sapropel 1 period separately.

\section{Results}

\subsection{Bulk Geochemistry}

[22] Both cores studied (Figure 3) show generally low values in $\mathrm{Mn} / \mathrm{Al}$ and high values in U/Th during the deglacial period $(17-10 \mathrm{ka})$, indicating dominantly reducing conditions [Mangini et al., 2001]. Values in $\mathrm{Mn} / \mathrm{Al}$ are notably low during this period compared to values typical of the mid-late Holocene, which are generally $>0.01$ for both locations, and represent the most strongly reducing conditions in the last $40 \mathrm{ka}$ in core 975B [JimenezEspejo et al., 2007b]. However, significant variability is present in both ratios, in addition to important differences that occur between parameters and between cores. We will therefore discuss the records in turn.

\subsubsection{The 300G Record $(1860 \mathrm{~m}$, Northern Alboran Slope): Figure 3a}

[23] High $\mathrm{Mn} / \mathrm{Al}(\sim 0.015)$ and low U/Th $(\sim 0.4)$ indicate that dominantly oxidizing conditions prevailed during the LGM, with maximum oxidation occurring between 19 and $18 \mathrm{ka}$. Generally speaking, the two parameters agree well, the exception being at the top of the record where U/Th falls independent of stable, low Mn/Al. This may represent "burn down" of the U subsequent to the return of oxidizing conditions [Mangini et al., 2001].

[24] At $\sim 18 \mathrm{ka}$, both parameters show an abrupt transition to values indicating reducing conditions ( $\sim 0.01$ for $\mathrm{Mn} / \mathrm{Al}$ and $\sim 0.625$ for $\mathrm{U} / \mathrm{Th}$ ) and $\mathrm{Mn} / \mathrm{Al}$ (U/Th) continues to gradually fall (rise) until $11 \mathrm{ka}$. Transition from relatively oxidized to relatively reduced conditions in U/Th occurs rather later (17.5 ka) than it does in Mn/Al (18.2 ka). The most reducing conditions are reached between 11.5 and $11 \mathrm{ka}$, reflected by values $\sim 0.008$ in $\mathrm{Mn} / \mathrm{Al}$. Within this trend, some variability is present. Most notable is the local minimum in $\mathrm{Mn} / \mathrm{Al}$ (maximum in U/Th) centered on $16 \mathrm{ka}$ which immediately precedes a local maximum in $\mathrm{Mn} / \mathrm{Al}$ (minimum in $\mathrm{U} / \mathrm{Th}$ ) centered on $15.5 \mathrm{ka}$. A further minimum in $\mathrm{Mn} / \mathrm{Al}$ (maximum in U/Th) occurs between 15 and
$13.5 \mathrm{ka}$, after which the two proxy systems no longer have a close correlation.

\subsubsection{The 975B Record (2416 m, Northern Algero-Balearic Basin): Figure 3b}

[25] As in 300G, this record essentially shows a transition from relatively oxidized conditions (0.013 in $\mathrm{Mn} / \mathrm{Al} ; 0.25$ in U/Th) during the LGM to relatively reducing conditions during the deglacial $(0.0075$ in $\mathrm{Mn} / \mathrm{Al} ; 0.6$ in $\mathrm{U} / \mathrm{Th})$. Initial transition to relatively reducing conditions occurs at $18 \mathrm{ka}$ both in $\mathrm{Mn} / \mathrm{Al}$ and U/Th. A reversal of the trend occurs, most strongly expressed in Mn/Al, between 17.5 and $15.5 \mathrm{ka}$, with a local minimum $(\mathrm{Mn} / \mathrm{Al} \sim 0.009)$ centered at $16.6 \mathrm{ka}$ and a local maximum $(\mathrm{Mn} / \mathrm{Al} \sim 0.11)$ at $15.8 \mathrm{ka}$. Maximum reducing conditions occur in both data series at $11 \mathrm{ka}$. Immediately subsequent to $11 \mathrm{ka}$, values in $\mathrm{U} / \mathrm{Th}$ decline abruptly which is not reflected in $\mathrm{Mn} / \mathrm{Al}$, perhaps as a result of "burn down" as above.

\subsection{Organic Geochemistry}

[26] Figure 4 shows records of TOC and the mass of 37-alkenones per gram of sediment for the deep Alboran Sea Basin during the last 30 ka that well reflect the timing of the canonical ORL1 (14.5-8.2 ka) reported by previous authors [Cacho et al., 2002b; Martinez-Ruiz et al., 2003]. Both records show significantly enhanced values during the period of the deglaciation, though in detail the records reveal some differences. TOC begins to rise at approximately $19 \mathrm{ka}$, leading the 37-alkenone record by $\sim 2$ ka. Both parameters rise gradually before $14.5 \mathrm{ka}$, at which time they abruptly increase to values of $\sim 1200 \mathrm{ng} \mathrm{g}^{-1}$ for the 37-alkenones and $\sim 0.8 \%$ for TOC. Both records show three local maxima, the last separated by a significant "saddle," though the timings of these differ somewhat. TOC peaks earlier in all three cases. The first peak $\left(0.84 \%\right.$ TOC; $1600 \mathrm{ng}$ alkenones $\left.\mathrm{g}^{-1}\right)$ is centered on $14 \mathrm{ka}$ for TOC as opposed to $13.5 \mathrm{ka}$ for the alkenones. The second, most strongly expressed peak $\left(0.92 \%\right.$ TOC; $1700 \mathrm{ng}$ alkenones $\left.\mathrm{g}^{-1}\right)$ is centered on $12.75 \mathrm{ka}$ for TOC as opposed to $12.25 \mathrm{ka}$ for the alkenones. In both records, the "saddle" extends from approximately $12 \mathrm{ka}$ to nearly $10 \mathrm{ka}$ before the final and most weakly expressed peak (up to $0.8 \%$ TOC; $\sim 1000 \mathrm{ng}$ alkenones $\mathrm{g}^{-1}$ ). The 37 -alkenone record indicates that minimum values during the "saddle" period were comparable with the highest values found during the late glacial period (down to $400 \mathrm{ng}$ alkenones $\mathrm{g}^{-1}$ ). 


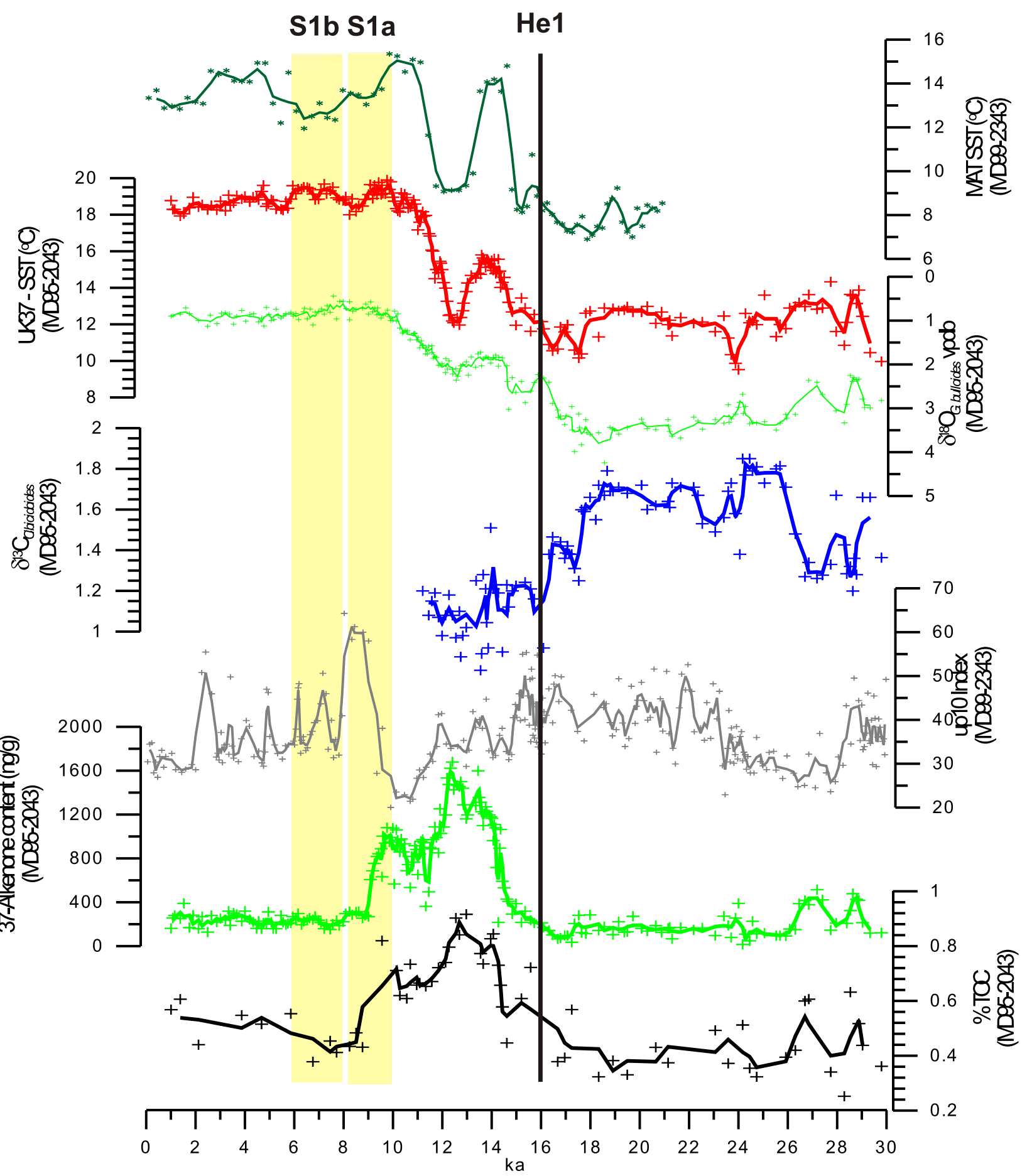

Figure 4. Indicators of bottom ventilation in the Alboran Sea from core MD95-2043 during the last deglaciation. Also shown is the bottom velocity (UP10) record from MD99-2343 [Frigola et al., 2008] and the winter SST record for the same core. All methods are described in section 3.2. Lines represent 3-point moving averages. The duration of deposition of sapropel 1 is indicated, including the duration of the interruption.

\subsection{Planktonic and Benthic Isotopic Records}

[27] The benthic carbon isotope curve ends during the termination, at the time of the ORL 1 deposi- tion, due to the disappearance of the C. pachyder$m u s$ and reflecting a severe decrease in the oxygen content of the deep basin. The $\delta^{13} \mathrm{C}$ record shows a depletion at the onset of the deglaciation and in parallel to a surface water freshening indicated by 
the G. bulloides $\delta^{18} \mathrm{O}$. HE 1 is represented in both isotopic records by a large excursion toward lighter values indicating the occurrence of a significant surface freshening in parallel to deterioration of the deep conditions. The $\delta^{13} \mathrm{C}$ record from $C$. pachydermus indicates that oxygen depletion in the deep western Mediterranean basin started before the beginning of the ORL 1 deposition, as is also suggested by the other records.

\subsection{Grain Size Distribution}

[28] The UP10 record of MD99-2343 (Figure 4) indicates a declining bottom velocity at $15 \mathrm{ka}$, coincident with the onset of high TOC values. However, despite a prominent local minimum coincident with Heinrich Stadial 1, the record does not present changes outside of normal variability before this time. Minimum UP10 values occur between 12 and $10 \mathrm{ka}$. Subsequent to $10 \mathrm{ka}$, UP10 values abruptly increase to reach maximum values between 9 and $8 \mathrm{ka}$. Local maxima in UP10 between 14.5 and $10 \mathrm{ka}$ coincide with local minima in TOC.

\subsection{Buoyancy Forcing}

[29] Figure 5 shows the estimated density record for surface water in the western Mediterranean basin over the last $20 \mathrm{ka}$, showing a substantial gain in buoyancy over this period. This buoyancy gain is due to the coincidence of opposite-sign changes in winter sea surface temperature (wSST) and the salinity of the Mediterranean water mass over this period. The impact of temperature (red line in Figure 5) is relatively small, resulting in a total density loss $\sim 1 \mathrm{~kg} \mathrm{~m}^{-3}$, and is relatively noisy due to short-term variability in wSST through the Bølling-Allerød and Younger Dryas. However, the majority of its influence occurs in abrupt transitions at Terminations $1 \mathrm{a}$ and $1 \mathrm{~b}$. The scale of the buoyancy change due to ocean mean salinity change driven by dilution during ice cap retreat $\left(\sim 0.9 \mathrm{~kg} \mathrm{~m}^{-3}\right.$; broken blue line in Figure 5) is similar in magnitude to that related to changes in wSST.

[30] The response of the Mediterranean system to deglacial reduction in the constriction on the outflow via the Strait of Gibraltar was primarily to freshen [Myers, 2002; Rohling and Bryden, 1994]. This caused the salinity gradient across the Strait to decrease and mean Mediterranean water to become increasingly similar to Atlantic Central Water [Myers, 2002; Rogerson et al., 2005; Rohling and Bryden, 1994]. The scale of the buoyancy gain due to changes in $\Delta \mathrm{S}_{\text {gib }}$ (dotted blue line in Figure 5) is equivalent in scale to that of the changes due to oceanic salinity and temperature combined $\left(\sim 1.7 \mathrm{~kg} \mathrm{~m}^{-3}\right)$, and drives most of the total density change (Figure 5, black line). The scale of this total change, $\sim 3.7 \mathrm{~kg} \mathrm{~m}^{-3}$, is significant; for comparative purposes, this change is more than double the modern density difference at the Strait of Gibraltar and is $\sim 60$ times larger than the density difference between Levantine Intermediate Water and West Mediterranean Deep Water $\left(0.02 \mathrm{~kg} \mathrm{~m}^{-3}\right.$ [Kinder and Bryden, 1990]).

\subsection{Change in Aspiration Conditions}

[31] As the force driving aspiration of WMDW (equation (2)) is coupled to the size of the density gradient at Gibraltar (which is essentially $\Delta \mathrm{S}_{\text {gib }}$ ), it is not surprising to note that the maximum depth of aspiration ("stagnation depth") shoaled substantially during the last deglacial (Figure 6). The deepest reconstructed value for the stagnation depth is $1155 \mathrm{~m}$ immediately before T-1a, though this may be an artifact of the sparse sampling in the sea level curve between 17 and $14.5 \mathrm{ka}$. The stagnation depth shoaled rapidly between 14.5 and $\sim 13 \mathrm{ka}$ and continued to rise more slowly until nearly $7 \mathrm{ka}$, albeit with two significant reversals in this trend at $\sim 12.7 \mathrm{ka}$ and $11 \mathrm{ka}$.

[32] Consequently, it can be assumed that as sea level rose aspiration of WMDW became increasingly impaired relative to its state during the LGM. The interface between LIW and WMDW would therefore have shoaled over this period as the equilibrium level shifted, during which period export of WMDW by aspiration and other processes must be assumed to be exceeded by supply. Unless this time is characterized by a coincidental increase in the production of WMDW, this must be achieved by a decrease in export. Particularly noteworthy is the rapid shoaling (by $\sim 280 \mathrm{~m}$ ) of the maximum depth of aspiration between $\sim 14.5$ and $\sim 13 \mathrm{ka}$ (Figure 6). Assuming a surface area for the western Mediterranean of $8.5 \times 10^{11} \mathrm{~m}^{2}$, this would require an increase in the volume of the reservoir of WMDW by $2.38 \times 10^{14} \mathrm{~m}^{3}$, equivalent to approximately $1.6 \times 10^{11} \mathrm{~m}^{3} \mathrm{a}^{-1}$ or $5 \times$ $10^{-3} \mathrm{~Sv}$. If this flux was entirely achieved by reduction in export through the Strait of Gibraltar, this would account for a $\sim 10 \%$ reduction in the modern export of WMDW. Notable reversals in the trend toward shoaling of the stagnation depth are significant, as they are driven by changes in SST in the western Mediterranean. Their most important impact is to cause a period of negligible net 

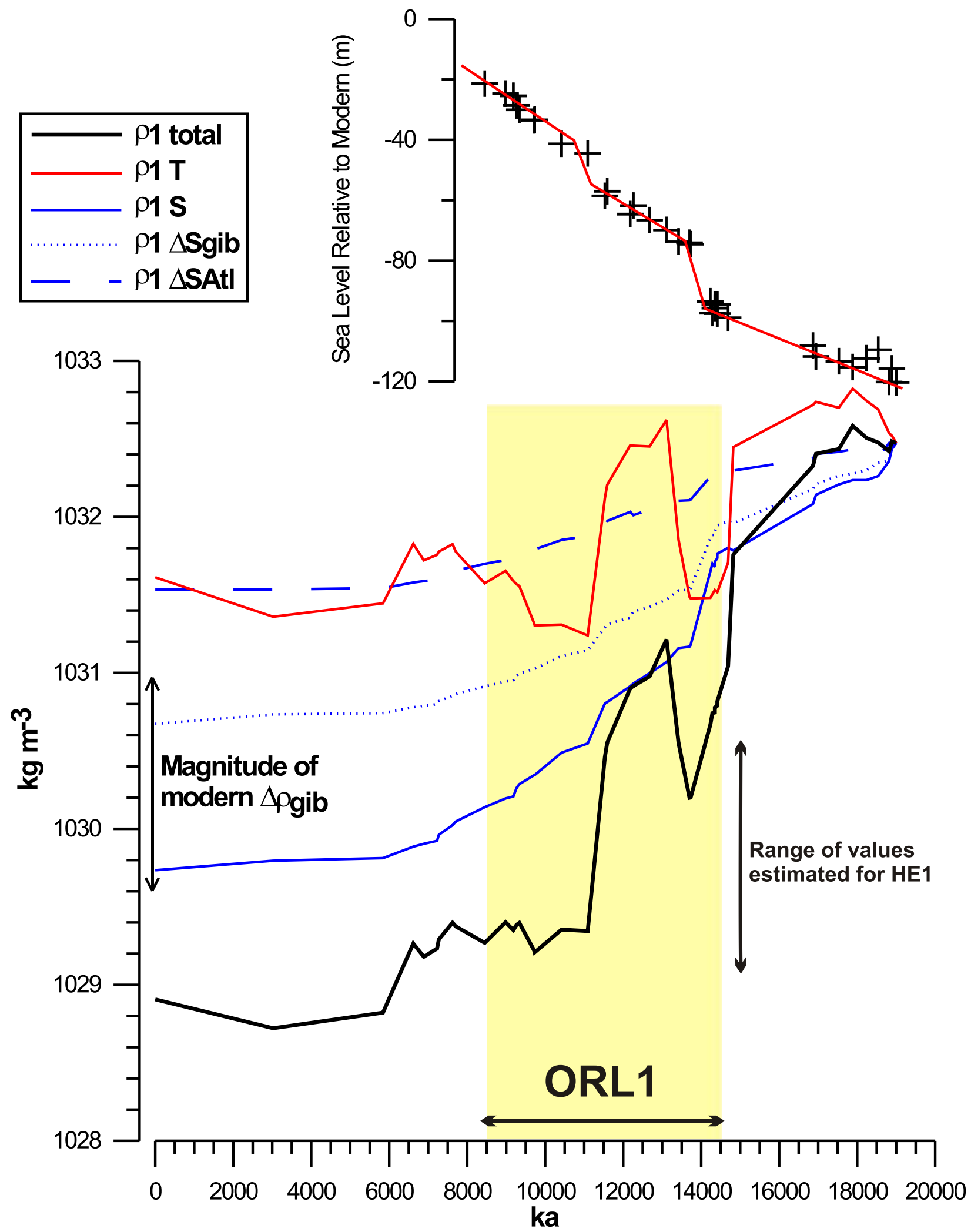

Figure 5. Record of the estimated potential density (s1) of newly produced WMDW. Sea level curve used for calculations shown above [Fairbanks, 1989; Bard et al., 1996]. The duration of ORL1 is shown, taken from JimenezEspejo et al. [2007b]. 


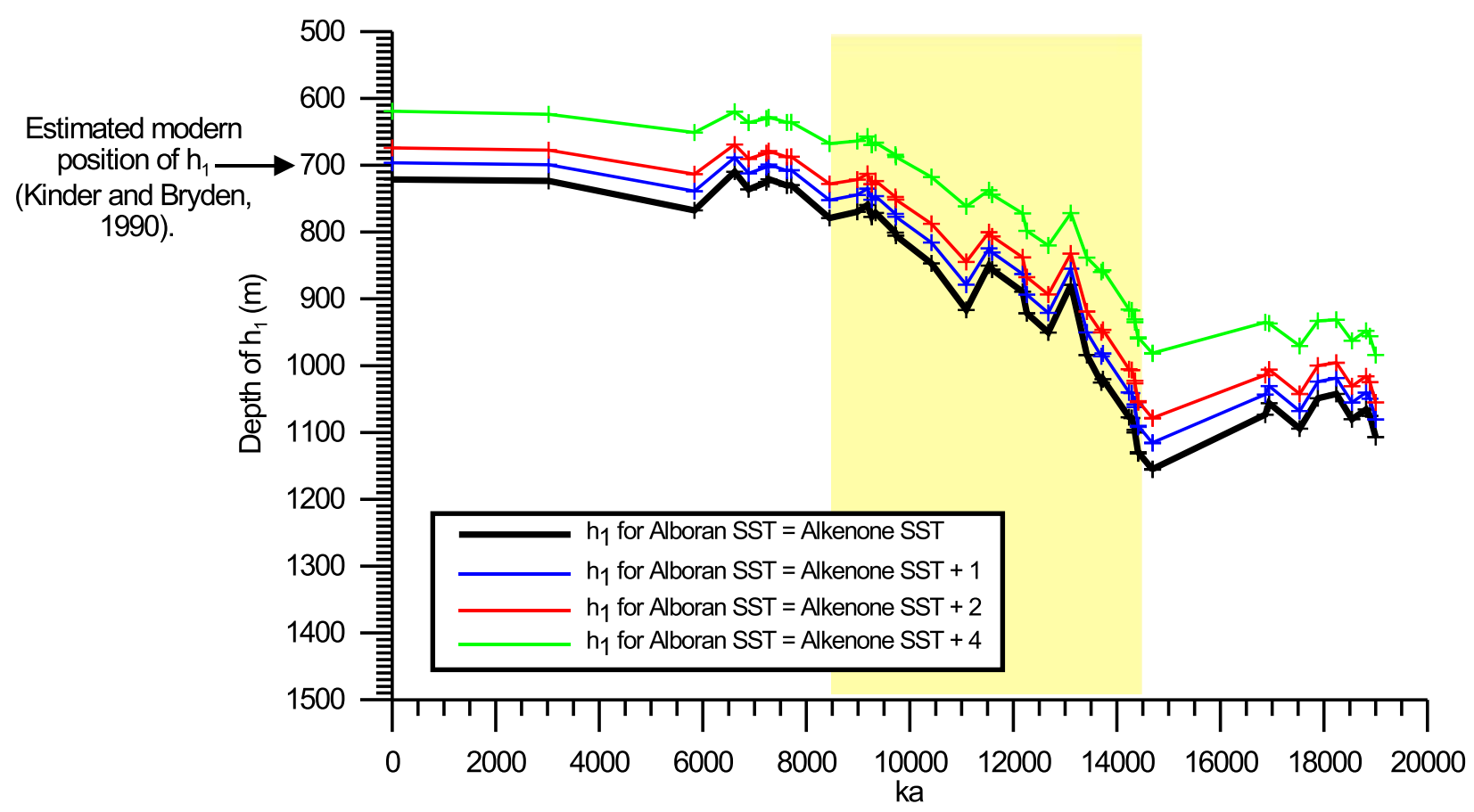

Figure 6. Changes in the stagnation depth (h1) within the Alboran Sea. Different lines represent different parameterizations of the Alboran Sea mean SST. Duration of ORL1 is indicated, taken from Figure 4. Stagnation depth estimates for HE1 are in the range 1611.7 to $2139.7 \mathrm{~m}$.

shoaling of the stagnation depth between $\sim 13$ and $\sim 10.2$ ka, highly reminiscent of the "saddle" in the organic geochemical records.

\subsection{Impact of Heinrich Event 1}

[33] The impact of the freshwater influx described by Sierro et al. [2005] on modeled hydrography are dramatic, with synchronous decrease in surface density by $\sim 1.5$ to $3 \mathrm{~kg} \mathrm{~m}^{-3}$ (Figure 5) and increase in stagnation depth by $600-1000 \mathrm{~m}$. It is important to recognize that the sign of the change in stagnation depth as a response to freshwater forcing is opposite to that of the rising sea level case, a consequence of an opposite-signed change in $U_{t}$ which is estimated to have increased by a factor of $1.5-2$ as a response to the change in $\Delta S_{\text {gib }}$. As the Alboran Sea is $\sim 2000 \mathrm{~m}$ deep, this suggests that even the deepest parts of WMDW may have been directly aspirated during this period.

\section{Discussion}

\subsection{Ventilation Changes in the Deep Western Mediterranean and Deglacial Sea Level Rise}

[34] Although there is some spatial and temporal complexity, the records presented in Figures 3 and
4 all show that a period of low oxygen bottom conditions relative to either the LGM or the middle-late Holocene occurred during the last deglaciation. Onset of reduced bottom oxygenation is at or immediately subsequent to $18 \mathrm{ka}$ preceding an abrupt decrease at $14.5 \mathrm{ka}$ and terminates either at $8.2 \mathrm{ka}$ or $10 \mathrm{ka}$, depending on the record. The UP10 record also indicates reduction of WMDW flow at $18 \mathrm{ka}$, but unchanged flow between 18 and $15 \mathrm{ka}$. A substantial fall in WMDW flow is noted at $14.5 \mathrm{ka}$, coincident with onset of enhanced TOC deposition. It should further be noted that the UP10 index for the Menorca Rise shown in Figure 4 indicates a prominent maximum in velocity between 8 and $9 \mathrm{ka}$. This confirms that the later date is the more representative, and the behavior of the bulk geochemical proxies are influenced by burn down (see section 4.1). The timing of onset and termination of bottom dysoxia bears little resemblance to the established period of freshwater forcing in the eastern Mediterranean during Sapropel 1 [Rohling, 1994] or to the orbital monsoon index [Rossignol-Strick and Paterne, 1999] but does correspond extremely well to the period of rapid sea level increase recorded in coral data [Bard et al., 1996; Fairbanks, 1989].

[35] However, despite the structural similarity of these records with regard to the timing of onset and 
termination of reduced ventilation, the records indicate different timing of the period of minimum ventilation. Bulk geochemical and bottom velocity proxies coherently indicate maximum dysoxia was reached toward the end of the deglacial period (at $\sim 11 \mathrm{ka}$ ) whereas the organic geochemical proxies suggest a date closer to $\sim 13$ ka (i.e., the BøllingAllerød). It is likely this represents some overprint by productivity in those proxies linked to conditions in the surface system $\left(\mathrm{C}_{\text {org }}\right.$, alkenone content, $\delta^{13} \mathrm{C}$ ), suggesting that the Bølling-Allerød was a time of enhanced nutrient supply to the surface of the Alboran Sea. This concept is strongly supported by $\mathrm{Ba}_{\text {excess }}$ and diatom records of productivity in this region, which indicate significant peaks in export flux during the deglacial period, particularly the Younger Dryas and Heinrich Event 1 [Bárcena et al., 2001; Jimenez-Espejo et al., $2007 \mathrm{~b}]$. It is informing to note that the peak periods of TOC (organic preservation) are not synchronous with peak $\mathrm{Ba}_{\text {excess }}$ (export flux) reported by JimenezEspejo et al. [2007b], indicating that though productivity is clearly influencing bottom dysoxia, it is not capable of dominating over ventilation changes.

\subsection{A Dynamic Mechanism for the Origin of Decreased Ventilation in the Western Mediterranean During Deglacial Periods}

[36] It is known that WMDW is not produced every winter, as conditions do not always become sufficiently cold [Millot, 1999; Schott et al., 1996]. In winters in which new WMDW is not formed, water subducted from the Gulf of Lions forms an intermediate layer (positioned between WMDW and WIW) at $\sim 1500 \mathrm{~m}$ [Millot, 1999; Schott et al., 1996], above the depth of the records presented in this study. We propose that during the last deglacial, the dense waters produced in the Gulf of Lions were injected at intermediate depth more often than at bottom depth, i.e., that conditions were perennially similar to the "warm winter" situation outlined above. Under these conditions, convection in the western Mediterranean would occur primarily above $2000 \mathrm{~m}$, isolating the water mass below this depth, and would generate the pattern of WMDW settling depth during this period described by Frigola et al. [2008]. This mechanism is outlined in Figure 7.

[37] In the model proposed, displacement of existing "old" WMDW (we propose the term "Old Bottom Water," OBW, following Casford et al. [2003]) is systematically impaired during the period of freshening related to deglacial sea level rise and declining $\Delta \mathrm{S}_{\text {gib }}$. Contemporary warming of the surface layer can be expected further to impair displacement of the relatively cold OBW. Consequently, deep ventilation will also be impaired and the rate of oxygen supply reduced, moving the system toward dysoxia. Decoupling of density changes in the surface and bottom layers implies that bottom ventilation will generally decline through time, until a large flux of new WMDW is produced that is capable of displacing OBW. Therefore, it would be expected to find an asymmetric behavior in bottom water oxygenation, with gradually declining bottom ventilation reaching a maximum close to the end of the period of OBW occurrence, followed by rapid and abrupt recovery. This asymmetry is highly consistent with the firstorder trends of sediment redox and bottom velocity proxies (Figures 4 and 5). Deep accumulation of salt in the western Mediterranean under deglacial conditions highly analogous to this model has been previously reported from modeling studies [Matthiesen and Haines, 2003].

[38] The spatial extent of ORL1 is highly suggestive that the above model is not a fully adequate mechanism for driving deep dysoxia, however, as the buoyancy changes found in the western basin will be reflected in the eastern basin. It is in this context that we highlight the reduction in the aspiration force. The steady shoaling of the interface between the WMDW and the LIW that is indicated in Figure 6 requires the WMDW/OBW system to be in a state of disequilibrium through this period, as the export of deep water must be exceeded by the import. From the arguments above, we expect dense waters produced in the Gulf of Lions to be injected at intermediate rather than bottom depths and the combined implications of this are significant, as import of new WMDW needed to raise the interface would therefore have been extremely slow. If new WMDW were produced at roughly $10 \%$ of its modern rate (reduced rates of WMDW production are supported by the UP10 record presented in Figure 4), export flux of WMDW + OBW via aspiration would be effectively 0 between 14.5 and $13 \mathrm{ka}$. The rate of loss of oxygen depleted OBW from the deep western basin can therefore be assumed with some confidence to be significantly impeded.

[39] The coherence of predicted hydrographic changes with evidence of reduced bottom oxygenation are striking. Onset of density loss and stagnation depth shoaling is $\sim 18 \mathrm{ka}$ with the largest 


\section{Holocene}
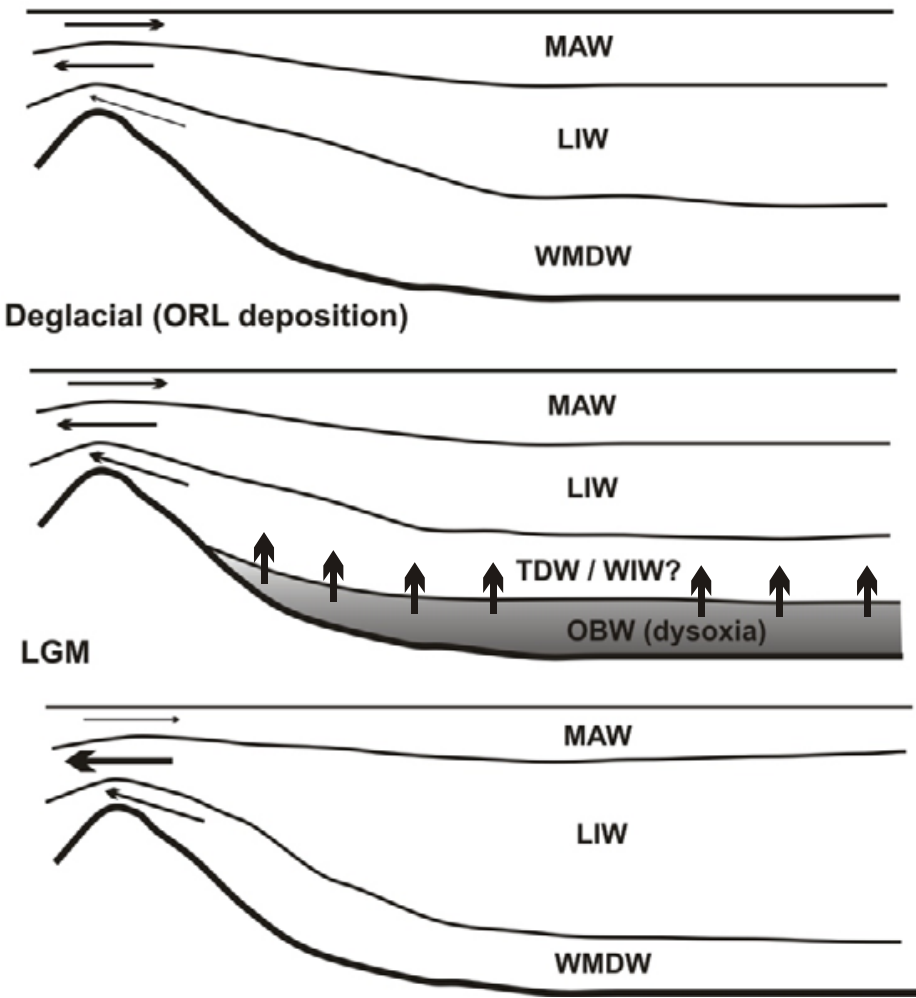

Figure 7. Conceptual model for development of western Mediterranean ORLs.

abrupt change being at Termination $1 \mathrm{a}(\mathrm{T} 1 \mathrm{a} ; 14.5 \mathrm{ka})$, in close correspondence with the empirical records. Rate of change in Figures 5 and 6 peak during the Bølling-Allerød and decline subsequently, essentially reaching equilibrium by $\sim 8 \mathrm{ka}$, which compares well with the organic geochemical records. Also, the most prominent internal feature of the geochemical records shown in Figures 3 and 4 is the "saddle" between 13 and $10 \mathrm{ka}$ in the organic parameters. This corresponds well to reversals in the trend of both the surface density (Figure 5) and stagnation depth (Figure 6) and so is also an inherent feature of our hydrographic model. Trend reversals are derived from local minima in SST related to the Younger Dryas and an older cooling centered on $12.6 \mathrm{ka}$ and coincide with local maxima in UP10. Together with the coincidence of the T1a warming with onset of ORL deposition, this implicates some control on deep ventilation from atmospheric thermal forcing.

[40] The proposed model also offers a potential explanation for the enhanced surface productivity conditions during the deglacial period, as the shoaling of the circulation (via physical shoaling of LIW and injection of the deglacial equivalent to WMDW at intermediate depths) would be expected to cause shoaling of the nutricline, in close analogy to the process suggested for the sapropels [Rohling, 1994]. The timing of peak export fluxes in the Alboran Sea (F. J. Jimenez-Espejo et al., Oceanographic variability in the westernmost Mediterranean since the Last Glacial Maximum: detrital input, productivity fluctuations and water mass circulation, submitted to Geochemistry, Geophysics, Geosystems, 2008) coincide well with periods of maximum shoaling of WMDW (Terminations 1a and $1 \mathrm{~b}$ and Heinrich Event 1), providing some support for this concept.

\subsection{Transient Freshwater Forcing: The Final Piece of the Puzzle?}

[41] In this model, it is not necessary to seek for a source of freshwater to "hose" into the northwestern Mediterranean throughout the last deglaciation that is large enough to perturb deep ventilation under modern or LGM boundary conditions. A relatively small, transient source of freshwater sufficient to isolate OBW long enough for the surface system to significantly evolve may be all that is required. It is in this context that we highlight the enhanced runoff during the period 
of ORL1 deposition recognized in the northwestern Mediterranean [Frigola et al., 2008] and in the Alboran Sea (F. J. Jimenez-Espejo et al., submitted manuscript, 2008). In particular, we highlight spikes in runoff in core TTR14-304G centered on Terminations $1 \mathrm{a}$ and $1 \mathrm{~b}$ (F. J. Jimenez-Espejo et al., submitted manuscript, 2008), which are coincident with times of weakest ventilation and are most likely to coincide with draining of the mountain glacial freshwater reservoir [Ivy-Ochs et al., 2007] and so, potentially, reflect transient decreases in the local evaporative flux.

\subsection{Heinrich Event 1 and the Role of LIW}

[42] Given the model described in the previous section, the change in western Mediterranean surface density attributed to Heinrich Event 1 in Figure 5 should have resulted in isolation of deep waters and the deposition of organic-enriched sediment. However, the records of deep ventilation presented in Figures 3 and 4 show an ambiguous picture between 16 and $17 \mathrm{ka}$, with rising (but not maximum) TOC and alkenone content, declining (but not minimum) $\delta^{13} \mathrm{C}_{\text {Cibicidoides }}$ and either local maxima (975B) or minima (300G) in $\mathrm{Mn} / \mathrm{Al}$. This suggests that the impact of the HE1 freshening was to move deep convection in the western Mediterranean into a weak state but not as weak a state as occurred $1.5 \mathrm{ka}$ later. This picture compares favorably with that of Frigola et al. [2008]. Consequently, bottom oxygenation decreased but in a muted manner relative to the scale of the surface freshening. It therefore does not appear to be the case that the influx of freshwater during Heinrich Events triggered formation of isolated OBW, as might be expected.

[43] We propose that the muted response of the deep western Mediterranean system to the strong HE1 forcing is attributed to the predicted coincident increase in westward flux, and consequently aspiration, during this time. Enhanced transport at intermediate depth within the Mediterranean analogous to this has been found in circulation models designed to investigate the impact of Heinrich-type freshwater forcing (G. Bigg, personal communication, 2007). That export flux via Gibraltar was enhanced during Heinrich Stadials is given strong support by observation that these periods were associated with maxima in flow of MOW on the slope of the Gulf of Cadiz, immediately west of Gibraltar [Llave et al., 2006; Rogerson et al., 2005; Voelker et al., 2006]. A transient but significant increase in westward Mediterranean Outflow flux within Heinrich Stadial 1 also provides support for enhanced influence of MOW on the Portuguese margin at this time [Skinner and Elderfield, 2005]. The differing response of the system to the Heinrich forcing compared to the deglacial forcing highlights a fundamental difference between these two cases, in that the former originates from a change in $\Delta \mathrm{S}_{\text {gib }}$ (causing $\mathrm{U}_{\mathrm{t}}$ to rise) and the latter originates from a change in ocean depth (causing $U_{t}$ to fall). A consequence of this regulation is that Atlantic derived freshwater is an unlikely cause of isolation of deep waters in the Mediterranean during ORL1 time or any other; freshwater forcing must reduce $\Delta S_{\text {gib }}$ to be effective in developing OBW.

[44] Conversely, our results suggest that the internal hydrographic structure of the western Mediterranean was much modified by the impact of HE1, as reported by Sierro et al. [2005]. The substantial decrease in surface density in the western Mediterranean can be assumed to have caused the density difference between newly formed WMDW and LIW supplied from the eastern basin to be smaller and potentially reversed, casuing WMDW to shoal. A reduction in new bottom water advection is supported by Sierro et al. [2005], who show that transient depletions in benthic foraminiferal $\delta^{13} \mathrm{C}$ occur during Heinrich Stadials, and that these depletions are more pronounced in the Gulf of Lions than in the Alboran Sea. Were this depletion caused by shoaling of the stagnation depth, this spatial gradient would be expected to be reversed. Furthermore, the UP10 record from the Balearic slope further supports that WMDW was in a relatively weak (and/or shallow) mode of operation during Heinrich Events, a behavior strongly contrasting with the climatically similar DansgaardOeschger stadials [Frigola et al., 2008] and thus supportive of our model.

\subsection{Relationship Between ORLs and Sapropels}

[45] The observation that $U_{t}$ is of critical importance to the development of deep anoxia in the western Mediterranean suggests that the ventilation crises associated with eastern sapropel deposition may be propagated into the western basin by altering the properties of LIW. However, though ORL1 continued to form during the period of deposition of S1a, it terminated approximately coincident with the S1 interruption [De Rijk et al., 1999; Martinez-Ruiz et al., 2003], as indicated by the abrupt increase in bottom velocity on the Balearic Slope (Figure 4). Consequently, it must be 
assumed that though perturbation of deep ventilation in the east may inhibit deep ventilation in the west, this effect is of minor importance compared to local influences. Furthermore, the coincidence of recovery of deep ventilation in the west with transient deep ventilation in the east strongly suggests that the same forcing [Casford et al., 2003; De Rijk et al., 1999] was responsible for purging of OBW in both basins, but that unlike in the east formation of OBW did not recur in the west. Consequently, a significant difference in the state of the deep western circulation between S1a and $\mathrm{S} 1 \mathrm{~b}$ times must exist.

[46] Figures 5 and 6 suggest that just such a difference did exist, as during the early Holocene the rate of sea level rise was beginning to subside, particularly from $\sim 8 \mathrm{ka}$ onward. Consequently, the stagnation depth had already reached its approximate Holocene position by the time of the interruption and the WMDW budget would therefore have been in equilibrium. In addition, a cooling trend in wSST in the northwestern Mediterranean occurs from $\sim 9.5$ to $\sim 7 \mathrm{ka}$ [Reguera, 2004], balancing sea level influence and causing surface buoyancy to remain almost constant across this period. Once OBW had been purged, it was therefore extremely unlikely that another isolated deep water body could form. Enhanced surface buoyancy and impeded aspiration are therefore both required for western OBW to form, the absence of either, as occurred during HE1 and S1b times, providing potential for strong bottom ventilation.

[47] A possible exception to this picture is the deep Tyrrhenian Basin, which is considered to display similar behavior to the eastern Mediterranean [Krishnamurthy et al., 2000; Meyers and Arnaboldi, 2005]. This is the only part of the western Mediterranean to experience significant incursion of Eastern Mediterranean Deep Water, which contributes to the formation of TDW [Millot, 1999; Zodiatis and Gasparini, 1996]. Consequently, as dysoxic OBW formed in the eastern basin it would have leaked into the Tyrrhenian basin, displacing more oxygenated water and promoting organic carbon burial. Consequently, the Tyrrhenian Sea is more dependent on conditions east of Sicily than the other western basins.

\section{Conclusions}

[48] We propose a dynamic mechanism for the origin of western Mediterranean ORLs linked to coupled changes in surface layer buoyancy and in aspiration of WMDW forced primarily by changes in sea level. The changes in export of WMDW driven by changes in the shear force available for aspiration is highlighted as being of prime importance in determining the spatial extent of dysoxic bottom waters during these periods, but changes in SST to be dominant in determining collapses and resumptions of deep ventilation. We consider simultaneous enhancement of surface buoyancy and impedance of aspiration to be necessary for western OBW formation, a combination typical of times of rising sea level. Changes in the local precipitation/runoff in the western Mediterranean are considered to provide only a secondary control on ventilation. We highlight, however, that an appropriately timed pulse of excess freshwater (especially centered on $14.5 \mathrm{ka}$, when surface conditions are evolving most rapidly) may be of great importance in exaggerating the isolation of OBW described herein. Similarly, productivity is considered to provide a secondary control on ORL formation that should not be overlooked.

[49] The impact of Heinrich Event 1 on surface buoyancy in the western Mediterranean is found to be strong, but though WMDW production would have been impaired, a large scale increase in the velocity of LIW in the western basin, derived from an increased $\Delta S_{\text {gib }}$, probably compensated for this effect. Atlantic freshwater forcing is therefore excluded as a possibility for promoting ORL development. Despite the fact that likely reduction in $\Delta \mathrm{S}_{\text {Sicily }}$ during sapropel times could have impeded LIW formation and, consequently, aspiration of WMDW, this effect is found to be inadequate to force development of OBW in the western basin on empirical grounds. Consequently, we infer that once surface buoyancy and aspiration processes had ceased to evolve rapidly in the early Holocene, it was inevitable that ORL formation would terminate. Termination was assisted by atmospheric forcing related to the $8.2 \mathrm{ka}$ event, in close analogy to the S1 interruption, and subsequent to this the western Mediterranean attained approximately its modern circulation configuration. This provides precisely the same timing for development of the modern circulation system as is independently suggested from planktonic foraminiferal assemblage records from the Alboran Sea gyres [Rohling et al., 1995]. Deep anoxia in the western basin must therefore be considered to be independent of that of the eastern basin (with the exception of the deep Tyrrhenian Basin). 


\section{Acknowledgments}

[50] This study would never have been possible without the IMAGES/PAGES workshop on Circum-Iberia Palaeoceanography and Palaeoclimate in Peniche in 2007. We warmly thank the workshop participants, and particularly the conveners, Antje Voelker and Fatima Abrantes. We also thank Phil Meyers and an anonymous reviewer, whose comments improved the manuscript significantly, and Laurent Labeyrie and Antje Voelker for their careful and considerate editing. This work was supported by MEC grant CGL2006-13327-C04-04 (I.C., F.M.R., and F.J.E.), project GRACCIE project CONSOLIDER-INGENIO: REF. CSD2007-00067 (F.S., I.C., M.C., J.F.) and GCL projects 2005-00642/BTE and SA008C05 (F.S., M.I.R.). The Hull Environment Research Institute (M.R.), Ramon y Cajal program (I.C,) and Junta de Andalucia (Research Group RNM 179) and the JSPS (F.J.E.) are also thanked for their support. Our thanks to E. Abarca, E. Holanda, J. Montes, and C. Niembro for their laboratory assistance.

\section{References}

Allen, J. R. M., and B. Huntley (1996), The vegetation and climate of north-west Iberia over the last 14,000 years, J. Quat. Sci., 11, 125-147, doi:10.1002/(SICI)1099-1417 (199603/04)11:2<125::AID-JQS232>3.0.CO;2-U.

Allen, J. R. M., and B. Huntley (2000), Weichselian palynological records from southern Europe: Correlation and chronology, Quat. Int., 73-74, 111-125, doi:10.1016/ S1040-6182(00)00068-9.

Allen, J. R. M., W. A. Watts, and B. Huntley (2000), Weichselian palynostratigraphy, palaeovegetation and palaeoenvironment: The record from Lago Grande di Monticchio, southern Italy, Quat. Int., 73-74, 91-110, doi:10.1016/ S1040-6182(00)00067-7.

Astraldi, M., S. Balopoulos, J. Candela, J. Font, M. Gacic, G. P. Gasparini, B. Manca, A. Theocharis, and J. Tintore (1999), The role of straits and channels in understanding the characteristics of Mediterranean circulation, Prog. Oceanogr., 44, 65-108, doi:10.1016/S0079-6611(99)00021-X.

Bar-Matthews, M., A. Ayalon, M. Gilmour, A. Matthews, and C. J. Hawkesworth (2003), Sea-land oxygen isotopic relationships from planktonic foraminifera and speleothems in the eastern Mediterranean region and their implication for paleorainfall during interglacial intervals, Geochim. Cosmochim. Acta, 67, 3181-3199, doi:10.1016/S0016-7037(02) 01031-1.

Bárcena, M. A., I. Cacho, F. Abrantes, F. J. Sierro, J. O. Grimalt, and J. A. Flores (2001), Paleoproductivity variations related to climatic conditions in the Alboran Sea (western Mediterranean) during the last glacial-interglacial transition: The diatom record, Palaeogeogr. Palaeoclimatol. Palaeoecol., 167, 337-357, doi:10.1016/S0031-0182(00) 00246-7.

Bard, E., B. Hamelin, M. Arnold, L. Montaggioni, G. Cambioch, G. Faure, and F. Rougerie (1996), Deglacial sea-level record from Tahiti corals and the timing of global meltwater discharge, Nature, 382, 241-244, doi:10.1038/382241a0.

Bethoux, J. P., and B. Gentili (1999), Functioning of the Mediterranean Sea: Past and present changes related to freshwater input and climate changes, J. Mar. Syst., 20, 33-47, doi:10.1016/S0924-7963(98)00069-4.
Bryden, H. L., and T. Kinder (1991), Steady two-layer exchange through the Strait of Gibraltar, Deep Sea Res., Part A, 38, S445-S463.

Bryden, H. L., E. C. Brady, and R. D. Pillsbury (1988), Flow through the strait of Gibraltar, in Seminario Sobre la Oceanografia Fisica del Estracho de Gibraltar, edited by J. L. Almazan et al., pp. 166-194, SECEG, Madrid.

Cacho, I., J. O. Grimalt, C. Pelejero, M. Canals, F. J. Sierro, J. A. Flores, and N. Shackleton (1999), Dansgaard-Oesschger and Heinrich event imprints in Alboran Sea paleotemperatures, Paleoceanography, 14, 698-705, doi:10.1029/ 1999PA900044.

Cacho, I., J. O. Grimalt, and M. Canals (2002a), Response of the western Mediterranean Sea to the rapid climatic variability that occurred during the last 50,000 years: A molecular biomarker approach, J. Mar. Syst., 33-34, 253-272, doi:10.1016/S0924-7963(02)00061-1.

Cacho, I., F. Sierro, N. J. Shackleton, H. Elderfield, and J. Grimalt (2002b), Reconstructing Alboran Sea hydrography during the last organic rich layer formation, Geochim. Cosmochim. Acta, 66(A115).

Cacho, I., N. Shackleton, H. Elderfield, F. J. Sierro, and J. O. Grimalt (2006), Glacial rapid variability in deep-water temperature and $\delta^{18} \mathrm{O}$ from the western Mediterranean Sea, Quat. Sci. Rev., 25, 3294-3311, doi:10.1016/j.quascirev. 2006.10.004.

Canals, M., A. Maldonado, A. Mangini, and D. F. Williams (1982), Paleoenvironmental correlation between eastern and western Mediterranean Basins during Late Quaternary, in XXVIII Congrès-Assemblée Plénière of Commission International pour l'Exploration Scientifique de la Mer Méditerranée (CIESM). Rapp.P. V. Reun. Cons. Int. Explor. Mer Mediter., 28, 39-40.

Casford, J. S. L., E. J. Rohling, R. H. Abu-Zied, C. Fontanier, F. J. Jorissen, M. J. Leng, G. Schmiedl, and J. Thomson (2003), A dynamic concept for eastern Mediterranean circulation and oxygenation during sapropel formation, Palaeogeogr. Palaeoclimatol. Palaeoecol., 190, 103-119, doi:10.1016/S0031-0182(02)00601-6.

Causse, C., B. Ghaleb, N. Chkir, K. Zouari, H. Ben-Ouezdou, and A. Mamou (2003), Humidity changes in southern Tunisia during the Late Pleistocene inferred from U-Th dating of mollusc shells, Appl. Geochem., 18, 1691-1703, doi:10.1016/S0883-2927(03)00043-X.

Cramp, A., and G. O'Sullivan (1999), Neogene sapropels in the Mediterranean: A review, Mar. Geol., 153, 11-28, doi:10.1016/S0025-3227(98)00092-9.

De Rijk, S., A. Hayes, and E. J. Rohling (1999), Eastern Mediterranean sapropel S1 interruption: An expression of the onset of climatic deterioration around $7 \mathrm{ka}$ BP, Mar. Geol., 153, 337-343, doi:10.1016/S0025-3227(98)00075-9.

Fairbanks, R. G. (1989), A 17,000-year glacio-eustatic sea level record: Influence of glacial melting rates on the Younger Dryas event and deep-ocean circulation, Nature, 342, 637642, doi:10.1038/342637a0.

Farmer, D. M., and L. Armi (1986), Maximal two-layer exchange over a sill and contraction with barotropic flow, J. Fluid Mech., 164, 53-76, doi:10.1017/ S002211208600246X

Frigola, J., A. Moreno, I. Cacho, M. Canals, F. J. Sierro, J. A. Flores, and J. O. Grimalt (2008), Evidence of abrupt changes in Western Mediterranean Deep Water circulation during the last 50 kyr: A high-resolution marine record from the Balearic Sea, Quat. Int., 181, 88-104, doi:10.1016/ j.quaint.2007.1006.1016. 
Ivy-Ochs, S., H. Kerschner, and C. Schluchter (2007), Cosmogenic nuclides and the dating of Lateglacial and Early Holocene glacier variations: The Alpine perspective, Quat. Int., 164-165, 53-63, doi:10.1016/j.quaint.2006.12.008.

Jimenez-Espejo, F. J., F. Martinez-Ruiz, C. Finlayson, A. Paytan, T. Sakamoto, M. Ortega-Huerta, G. Finlayson, K. Iijima, D. Gallego-Torres, and D. Fa (2007a), Climate forcing and Neanderthal extinction in southern Iberia: Insights from a multiproxy marine record, Quat. Sci. Rev., 26, 836-852, doi:10.1016/j.quascirev.2006.12.013.

Jimenez-Espejo, F. J., F. Martinez-Ruiz, T. Sakamoto, K. Iijima, D. Gallego-Torres, and N. Harada (2007b), Paleoenvironmental changes in the western Mediterranean since the last glacial maximum: High resolution multiproxy record from the Algero-Balearic basin, Palaeogeogr. Palaeoclimatol. Palaeoecol., 246, 292-306, doi:10.1016/j.palaeo.2006.10.005.

Jung, M., J. Ilmberger, A. Mangini, and K. C. Emeis (1997), Why some Mediterranean sapropels survived burn-down (and others did not), Mar. Geol., 141, 51-60, doi:10.1016/ S0025-3227(97)00031-5.

Kallel, N., M. Paterne, J. C. Duplessy, C. Vergnaud-Grazzini, C. Pujol, L. Labeyrie, M. Arnold, M. Fontugne, and C. Pierre (1997), Enhanced rainfall in the Mediterranean region during the last sapropel event, Oceanol. Acta, 20, 697-712.

Kelly, M. A., S. Ivy-Ochs, P. W. Kubik, F. von Blanckenburg, and C. Schluchter (2006), Chronology of deglaciation based on $\mathrm{Be}-10$ dates of glacial erosional features in the Grimsel Pass region, central Swiss Alps, Boreas, 35, 634-643, doi:10.1080/03009480600690829.

Kinder, T. H., and H. L. Bryden (1990), Aspiration of deep waters through straits, in The Physical Oceanography of Sea Straits, NATO ASI Ser., Ser. C, vol. 318, edited by L. J. Pratt, pp. 295-319, Kluwer Acad., Norwell, Mass.

Kinder, T. H., and G. Parilla (1987), Yes, some of the Mediterranean outflow does come from great depth, J. Geophys. Res., 92, 2901-2906, doi:10.1029/JC092iC03p02901.

Krishnamurthy, R. V., P. A. Meyers, and N. A. Lovan (2000), Isotopic evidence of sea-surface freshening, enhanced productivity, and improved organic matter preservation during sapropel deposition in the Tyrrhenian Sea, Geology, 28, 263-266, doi:10.1130/0091-7613(2000)28<263:IEOSFE > 2.0.CO;2

Larrasoaña, J. C., A. P. Roberts, E. J. Rohling, M. Winklhofer, and R. Wehausen (2003), Three million years of monsoon variability over the northern Sahara, Clim. Dyn., 21, 689698, doi:10.1007/s00382-003-0355-z.

Larrasoaña, J. C., A. P. Roberts, A. Hayes, R. Wehausen, and E. J. Rohling (2006), Detecting missing beats in the Mediterranean climate rhythm from magnetic identification of oxidized sapropels (Ocean Drilling Program Leg 160), Phys. Earth Planet. Inter., 156, 283-293, doi:10.1016/j.pepi.2005. 04.017.

Levitus, S., and G. Isayev (1992), Polynomial approximation to the International equation of state for seawater, J. Atmos. Oceanic Technol., 9, 705-708, doi:10.1175/1520-0426(1992)009<0705: PATTIE $>2.0 . \mathrm{CO} ; 2$.

Llave, E., J. Schoenfeld, F. J. Hernandez-Molina, T. Mulder, L. Somoza, V. D. del Rio, and I. Sanchez-Almazo (2006), High-resolution stratigraphy of the Mediterranean outflow contourite system in the Gulf of Cadiz during the late Pleistocene: The impact of Heinrich events, Mar. Geol., 227, 241-262, doi:10.1016/j.margeo.2005.11.015.

Mangini, A., M. Jung, and S. Laukenmann (2001), What do we learn from peaks of uranium and of manganese in deep sea sediments?, Mar. Geol., 177, 63-78, doi:10.1016/ S0025-3227(01)00124-4.
Martinez-Ruiz, F., A. Paytan, M. Kastner, J. M. GonzalezDonoso, D. Linares, S. M. Bernasconi, and F. J. JimenezEspejo (2003), A comparative study of the geochemical and mineralogical characteristics of the S1 sapropel in the western and eastern Mediterranean, Palaeogeogr. Palaeoclimatol. Palaeoecol., 190, 23-37, doi:10.1016/S0031-0182(02) 00597-7.

Matthiesen, S., and K. Haines (2003), A hydraulic box model study of the Mediterranean response to postglacial sealevel rise, Paleoceanography, 18(4), 1084, doi:10.1029/ 2003PA000880.

Meyers, P. A., and M. Arnaboldi (2005), Trans-Mediterranean comparison of geochemical productivity proxies in a midPleistocene interrupted sapropel, Palaeogeogr. Palaeoclimatol. Palaeoecol., 222, 313-328, doi:10.1016/j.palaeo. 2005.03.020.

Millot, C. (1987), Circulation in the western Mediterranean Sea, Oceanol. Acta, 10, 143-149.

Millot, C. (1999), Circulation in the western Mediterranean Sea, J. Mar. Syst., 20, 423-442, doi:10.1016/S09247963(98)00078-5.

Millot, C., J. Candela, J. L. Fuda, and Y. Tber (2006), Large warming and salinification of the Mediterranean outflow due to changes in its composition, Deep Sea Res., Part I, 53, 656-666, doi:10.1016/j.dsr.2005.12.017.

Myers, P. G. (2002), Flux-forced simulations of the paleocirculation of the Mediterranean, Paleoceanography, 17(1), 1009, doi:10.1029/2000PA000613.

Naughton, F., M. F. S. Goni, S. Desprat, J. L. Turon, J. Duprat, B. Malaize, C. Joli, E. Cortijo, T. Drago, and M. C. Freitas (2007), Present-day and past (last 25000 years) marine pollen signal off western Iberia, Mar. Micropaleontol., 62, $91-$ 114, doi:10.1016/j.marmicro.2006.07.006.

Perez-Obiol, R., and R. Julia (1994), Climatic change on the Iberian Peninsula recorded in a 30,000-yr pollen record from Lake Banyols, Quat. Res., 41, 91-98, doi:10.1006/qres. 1994.1010.

Reguera, I. (2004), Respuesta del Mediterraneo occidental a los cambios bruscos ocurridos durante el ultimo ciclo glacial: Estudio de las asociaciones de foraminiferos, $231 \mathrm{pp}, \mathrm{Ph} . \mathrm{D}$ thesis, Univ. of Salamanca, Salamanca, Spain.

Reimer, P. J., et al. (2004), IntCal04 terrestrial radiocarbon age calibration, 0-26 cal kyr BP, Radiocarbon, 46, 1029-1058.

Rogerson, M., E. J. Rohling, P. P. E. Weaver, and J. W. Murray (2005), Glacial to interglacial changes in the settling depth of the Mediterranean outflow plume, Paleoceanography, 20, PA3007, doi:10.1029/2004PA001106.

Rogerson, M., E. J. Rohling, and P. P. E. Weaver (2006), Promotion of meridional overturning by Mediterraneanderived salt during the last deglaciation, Paleoceanography, 21, PA4101, doi:10.1029/2006PA001306.

Rohling, E. J. (1994), Review and new aspects concerning the formation of eastern Mediterranean sapropels, Mar. Geol., 122, 1-28, doi:10.1016/0025-3227(94)90202-X.

Rohling, E. J., and H. L. Bryden (1994), Estimating past changes in the eastern Mediterranean freshwater budget, using reconstructions of sea level and hydrography, Proc. K. Ned. Akad. Wet., Ser. B, 97, 201-217.

Rohling, E. J., and S. Cooke (1999), Stable oxygen and carbon isotopes in foraminferal carbonate shells, in Modern Foraminifera, edited by B. K. SenGupta, pp. 239-258, Kluwer Acad., London.

Rohling, E. J., and F. J. Hilgen (1991), The eastern Mediterranean climate at times of sapropel formation-A review, Geol. Mijnbouw, 70, 252-264. 
Rohling, E. J., M. DenDulk, C. Pujol, and C. Vernaud-Grazzini (1995), Abrupt hydrographic change in the Alboran Sea (western Mediterranean) around 8000 yrs BP, Deep Sea Res., Part I, 42, 1609-1619, doi:10.1016/0967-0637(95) 00069-I.

Rohling, E. J., et al. (2002), African monsoon variability during the previous interglacial maximum, Earth Planet. Sci. Lett., 202, 61-75, doi:10.1016/S0012-821X(02)00775-6.

Rohling, E. J., P. A. Mayewski, and P. Challenor (2003), On the timing and mechanism of millennial-scale climate variability during the last glacial cycle, Clim. Dyn., 20, 257-267.

Rossignol-Strick, M. (1999), The Holocene climatic optimum and pollen records of sapropel 1 in the eastern Mediterranean, 9000-6000 BP, Quat. Sci. Rev., 18, 515-530, doi:10.1016/S0277-3791(98)00093-6.

Rossignol-Strick, M., and M. Paterne (1999), A synthetic pollen record of the eastern Mediterranean sapropels of the last $1 \mathrm{Ma}$ : Implications for the time-scale and formation of sapropels, Mar. Geol., 153, 221-237, doi:10.1016/S00253227(98)00080-2.

Schott, F., M. Visbeck, U. Send, J. Fischer, L. Stramma, and Y. Desaubies (1996), Observations of deep convection in the Gulf of Lions, northern Mediterranean, during the winter of 1991/92, J. Phys. Oceanogr., 26, 505-524, doi:10.1175/ 1520-0485(1996)026<0505:OODCIT>2.0.CO;2.

Schrag, D. P., J. F. Adkins, K. McIntyre, J. L. Alexander, D. A. Hodell, C. D. Charles, and J. F. McManus (2002), The oxygen isotopic composition of seawater during the Last Glacial Maximum, Quat. Sci. Rev., 21, 331-342, doi:10.1016/S02773791(01)00110-X.

Seim, H. E., and M. C. Gregg (1997), The importance of aspiration and channel curvature in producing strong vertical mixing over a sill, J. Geophys. Res., 102, 3451-3472, doi:10.1029/96JC03415.

Sierro, F. J., et al. (2005), Impact of iceberg melting on Mediterranean thermohaline circulation during Heinrich events, Paleoceanography, 20, PA2019, doi:10.1029/ 2004PA001051.
Skinner, L. C., and H. Elderfield (2005), Constraining ecological and biological bias in planktonic foraminiferal $\mathrm{Mg} / \mathrm{Ca}$ and $\delta^{18}$ Occ: A multispecies approach to proxy calibration testing, Paleoceanography, 20, PA1015, doi:10.1029/ 2004PA001058.

Stommel, H. M. (1972), Deep winter-time convection in the western Mediterranean Sea, in Studies in Physical Oceanography, edited by A. L. Gordon, pp. 207-218, Gordon and Breach, New York.

Stommel, H. M., H. L. Bryden, and P. Mangelsdorf (1973), Does some of the Mediterranean outflow come from great depth?, Pure Appl. Geophys., 105, 879-889, doi:10.1007/ BF00875837.

Stuiver, M., and P. J. Reimer (1993), Extended ${ }^{14} \mathrm{C}$ data base and revised CALIB $3.0{ }^{14} \mathrm{C}$ age calibration program, Radiocarbon, 35, 215-230.

Stuiver, M., P. J. Reimer, E. Bard, J. W. Beck, G. S. Burr, K. A. Hughen, B. Kromer, G. McCormac, and M. Spurk (1998), INTCAL98 radiocarbon age calibration, 24,000-0 cal BP, Radiocarbon, 40, 1041-1083.

Ternois, Y., M. A. Sicre, A. Boireau, J. C. Marty, and J. C. Miquel (1996), Production pattern of alkenones in the Mediterranean Sea, Geophys. Res. Lett., 23, 3171-3174, doi:10.1029/ 96GL02910.

Trouwborst, R. E., B. G. Clement, B. M. Tebo, B. T. Glazer, and G. W. Luther III (2006), Soluble Mn (III) in suboxic zones, Science, 313, 1955-1957, doi:10.1126/science. 1132876.

Tsimplis, M. N., and H. L. Bryden (2000), Estimation of the transports through the strait of Gibraltar, Deep Sea Res., Part I, 47, 2219-2242, doi:10.1016/S0967-0637(00)00024-8.

Voelker, A. H. L., S. M. Lebreiro, J. Schoenfeld, I. Cacho, H. Erlenkeuser, and F. Abrantes (2006), Mediterranean outflow strengthening during northern hemisphere coolings: A salt source for the glacial Atlantic?, Earth Planet. Sci. Lett., 245, 39-55, doi:10.1016/j.epsl.2006.03.014.

Zodiatis, G., and G. P. Gasparini (1996), Thermohaline staircase formations in the Tyrrhenian Sea, Deep Sea Res., Part I, 43, 655, doi:10.1016/0967-0637(96)00032-5. 